\title{
Whiteness Studies II
}

An update on the new history of race in America

\section{Peter Kolchin}

\section{(2) OpenEdition}

\section{Journals}

Electronic version

URL: https://journals.openedition.org/jsa/12782

DOI: 10.4000/jsa. 12782

ISSN: 1957-7842

\section{Publisher}

Société des américanistes

\section{Printed version}

Date of publication: 23 July 2009

Number of pages: 144-163

ISSN: 0037-9174

\section{Electronic reference}

Peter Kolchin, "Whiteness Studies II", Journal de la Société des américanistes [Online], 95-1 | 2009,

Online since 10 June 2014, connection on 02 September 2022. URL: http://journals.openedition.org/ jsa/12782 ; DOl: https://doi.org/10.4000/jsa. 12782 


\title{
WHITENESS STUDIES
}

\author{
Peter KOLCHIN *
}

Over the past two decades, scholars in the social sciences and humanities have increasingly focused on "whiteness " as a new way of exploring race and racism in America. These two articles evaluate the way historians have approached the subject. The first article, originally published in the Journal of American History in 2002, examines the development of whiteness studies in the 1990s, and the second, which appears here for the first time, provides an update on more recent trends. The articles find considerable potential in whiteness studies, but also point to serious conceptual and methodological problems that deserve attention. [Key words: whiteness, whiteness studies, race, racism.]

Études sur les Blancs. Au cours des deux dernières décennies, les études sur les Blancs se sont multipliées en sciences sociales et humaines et apparaissent comme une nouvelle voie d'accès à la question des races et du racisme aux États-Unis. Les deux textes présentés ici font un bilan de la façon dont les historiens ont traité le sujet. Le premier d'entre eux, publié initialement dans le Journal of American History en 2002, concerne le développement des études sur les Blancs dans les années 1990 ; le second, inédit, est une mise à jour sur les tendances les plus récentes. Tous deux montrent que les études sur les Blancs ont un potentiel analytique important, mais ils attirent également l'attention sur les difficultés conceptuelles et méthodologiques du domaine. [Mots-clés: Blancs, études sur les Blancs, race, racisme.]

Estudios sobre los blancos. Durante los últimos dos decenios, especialistas de ciencias sociales y humanas han concentrado cada vez más su atención sobre los estudios dedicados a los blancos como una nueva vía para explorar los temas de las razas y del racismo en los Estados Unidos. Los trabajos aquí presentados hacen un balance de la manera en que los historiadores han tratado ese problema. El primero de ellos, publicado inicialmente en el Journal of American History en 2002, concierne el desarrollo de los estudios sobre los blancos durante los años 1990, mientras que el segundo, inédito, da cuenta de las evoluciones más recientes. Si esos trabajos enseñan el gran potencial de este tipo de estudios, llaman al mismo tiempo la atención sobre algunas dificultades conceptuales y metodológicas que merecen ser tomadas en consideración. [Palabras claves: blancos, estudios sobre los blancos, razas, racismo.]

* Henry Clay Reed Professor of History at the University of Delaware, Department of History, University of Delaware, Newark, DE, 19716 [pkolchin@udel.edu].

Journal de la Société des Américanistes, 2009, 95-1, pp. 117-163. C Société des Américanistes. 


\section{THE NEW HISTORY OF RACE IN AMERICA ${ }^{1}$}

Suddenly whiteness studies are everywhere. The rapid proliferation of a genre that appears to have come out of nowhere is little short of astonishing: a recent keyword search on my university library's electronic catalog yielded fifty-one books containing the word " whiteness » in their titles, almost all published in the past decade and most published in the past five years ${ }^{2}$. All around us, American historians and scholars in related disciplines from sociology and law to cultural studies and education are writing books with titles such as The white scourge, How the Irish became white, Making whiteness, The possessive investment in whiteness, and Critical white studies ${ }^{3}$. Although the term " whiteness studies » might at first glance suggest works that promote white identity or constitute part of a racist backlash against multiculturalism and « political correctness », virtually all the whiteness studies authors seek to confront white privilege - that is, racism - and virtually all identify at some level with the political Left. Most of them see a close link between their scholarly efforts and the goal of creating a more humane social order.

Whiteness studies authors manifest a wide variety of approaches. In many of the disciplines outside history, prescriptive policy goals assume a central position; writing on whiteness in education, for example, Nelson M. Rodriguez calls for the creation of " "pedagogies of whiteness" as a counterhegemonic act " predicated on the need to " refigure whiteness in antiracist, antihomophobic, and antisexist ways » (Rodriguez 1998, p. 33). Although such didacticism is far from absent in the work of whiteness studies historians, their focus has been on the construction of whiteness - how diverse groups in the United States came to identify, and be identified by others, as white - and what that has meant for the social order. Starting from the now widely shared premise that race is an ideological or social construct rather than a biological fact, they have at least partially shifted attention from how Americans have looked at blacks to how they have looked at whites, and to whiteness as a central component of Americans' racial ideology. In doing so, they have already had a substantial impact on historians whose work does not fall fully within the rubric of whiteness studies but who have borrowed some of the field's insights, concerns, and language ${ }^{4}$.

This essay represents an effort by a sympathetic but critical outsider to come to grips with this burgeoning field. I will deal primarily with historical literature, although I will refer to works in other disciplines, and I will pay particular attention to two books that are among the best and most influential of the whiteness studies works: David R. Roediger's The wages of whiteness and Matthew Frye Jacobson's Whiteness of a different color ${ }^{5}$. Because the two books differ from each other in important respects, they reveal both the diversity within and the common assumptions behind whiteness studies, and they suggest some of 
the insights and potential pitfalls of the genre. My aim is to produce not so much a final evaluation of a finished project as a tentative progress report on a literature still very much in evolution ${ }^{6}$.

One of the earliest of the historical whiteness works, The wages of whiteness (1991) focuses on how white workers in the antebellum United States came to identify as white. Roediger's essential starting point is that because the white working class in the United States emerged in a slaveholding republic, its members came to define themselves by what they were not: slaves and blacks. Building on Alexander Saxton's analysis of the " ambivalent stance » of white workers in a racist society, Roediger pays particular attention to the efforts of Irish immigrants - who faced such extreme prejudice that « it was by no means clear that the[y] were white »-to differentiate themselves from black slaves, establish their own whiteness, and thereby prove their Americanness. (This argument receives further elaboration in Noel Ignatiev's suggestively titled book, How the Irish became white) ${ }^{7}$.

Roediger combines the emphasis on class that one would expect of a labor historian with some decidedly nontraditional - postmodern - touches. He displays a particular sensitivity to the significance of language, from metaphorical attacks on British «slavery » by American revolutionaries to use of the terms " wage slavery » and especially « white slavery » to describe the condition of free white workers; in rejecting the word « servant » in favor of « hand » or « help », he suggests, "farm and household workers... were becoming white workers who identified their freedom and their dignity in work as being suited to those who were "not slaves" and "not negurs" ". He also provides an intriguing if highly speculative psychological argument that as the country industrialized, the increasingly controlled and disciplined white population came to view blacks as their former, uninhibited selves, a perception highlighted in the " acting out» evident in the newly popular blackface and minstrelsy, in which participants could " both display and reject the "natural self" ". And, in a practice he shares with many other whiteness studies authors - especially those working in disciplines other than history - Roediger foregrounds himself and his subjective reaction to his subject, beginning the book with a personal narrative of his own route from a racist past (Roediger 1999, pp. 49, 116, 3-5).

Although Matthew Frye Jacobson's overall subject is the same as Roediger's - how people came to « be » white - his subjects are European immigrants to the United States over the long period from 1790 to 1965, and his focus is on how other Americans perceived those immigrants, not on their self-perception. Jacobson's broad scope enables him to depart from a binary (black/white) view of race and to explore the close, troubling, and troublesome relationship among race, ethnicity, and nationality ${ }^{8}$. Revealing the extraordinary malleability of American conceptualizations of race, Jacobson outlines a three-stage chronological 
progression of racial categorization. From the 1790s to the 1840s, in an era of relatively few immigrants, Americans saw people as either white or black. Between the 1840s and the 1920s, a period of massive foreign immigration and pervasive prejudice against various immigrant groups, there emerged a pattern of " variegated whiteness » in which some groups appeared better - whiter - than others. Finally, beginning in the 1920s, with immigration restriction, color again triumphed as a badge of race, and Americans came to see - and celebrate the diversity of - a " Caucasian " race that encompassed diverse nationalities previously deemed racially deficient. « To trace the process by which Celts or Slavs became Caucasians ", Jacobson writes, « is to recognize race as an ideological, political deployment rather than as a neutral, biologically determined element of nature » (Jacobson 1998, p. 14).

Although sharing Roediger's interest in the construction of race, his didactic goal in exposing that construction, and his belief in the centrality of race - and racism - to American history, Jacobson differs from Roediger in approaching the past almost entirely in cultural terms. Indeed, he suggests that in focusing too heavily on "class and economics ", Roediger is overly deterministic and misses " the full complexity of whiteness in its vicissitudes ». Dealing principally with perceptions of immigrants rather than with the immigrants themselves, Jacobson is more concerned with images and representations than with actual social relations. (This « American studies » approach is even more pronounced in Grace Elizabeth Hale's book Making whiteness, which delineates the emergence of a southern "culture of segregation » in the late nineteenth and early twentieth centuries). Nevertheless, the difference between Jacobson's approach and Roediger's is more one of degree than of essence: despite his focus on the working class, Roediger pays careful attention to cultural manifestations and is hardly an economic determinist. Indeed, as I will suggest below, if both Roediger and Jacobson start from the premise that race is artificial, constructed, and without inherent meaning, in some ways Roediger appears even less inclined than Jacobson to see race as a function of concrete - class - relationships ${ }^{9}$.

One's first reaction to Roediger's and Jacobson's books - and to the field of whiteness studies in general - is likely to be excitement. Indeed, even after repeated readings of these books (in conjunction with using them in graduate seminars), I still find myself sharing in the students' typical feelings of discovery and delight in a promising new way to look at history. But a vague yet persistent sense of unease is also a predictable response. Although the precise nature of the unease may emerge only gradually, it centers on the elusive, undefined nature of whiteness and on concern about overreliance on whiteness in explaining the American past.

In approaching both the excitement and the unease generated by whiteness studies, it is useful to begin with an understanding that underlies the entire genre. 
Whiteness studies authors build on what is now a historical (and biological and anthropological) commonplace: race is a "construct » rather than an objective way of explaining differences among human beings. There are varying versions of this process: historians typically refer to either the "social ", " historical », or « ideological » construction of race; according to the anthropologist Edgar T. Thompson, "races are made in culture, not found in nature »; the biologist Stephen Jay Gould rebuts what he terms « biological determinism » - the belief that « shared behavioral norms... arise from inherited, inborn distinctions ». But all the versions mean essentially the same thing: race is " made » by humans; how humans have assigned people to one race or another has varied dramatically over time and space; and racial categorizations have no intrinsic meaning or validity aside from the particular social circumstances that engender them ${ }^{10}$.

An almost infinite number of examples illustrate the constructed nature of race - and of whiteness in particular. Although the well-known « one-drop rule » dictates that in the United States anyone with the slightest bit of black « blood » be categorized as black, there is no particular logic to labeling people black who are part white and part black, and in some places they are not so labeled. Two possibly apocryphal stories drive home the arbitrary character of such racial categorization. According to one, the Haitian dictator Papa Doc Duvalier insisted that the Haitian population was 98 percent white. Asked by a puzzled American how this could be, he responded with a question: « How do you define black in your country? " " Receiving the explanation that in the United States anyone with any black blood was considered black, Duvalier nodded and said, "Well, that's the way we define white in my country" ". Equally telling is a story about the Mexican War: "When Americans marched into the Mexican city of Saltillo in 1847, they were greeted by a woman from New Jersey, who worked in a Mexican textile mill. "Americans I am glad to see you", she exclaimed. "I have seen but one white man in eight months, a negro from New Orleans" " ".

But perhaps the most striking example of the arbitrary and changing nature of race, cited by Jacobson, is to be found in Benjamin Franklin's remarkable classification of the world's population in 1751:

All Africa is black or tawny; Asia chiefly tawny; America (exclusive of the newcomers [that is, the English]) wholly so. And in Europe, the Spaniards, Italians, French, Russians, and Swedes are generally of what we call a swarthy complexion; as are the Germans also, the Saxons only excepted, who, with the English, make the principal body of white people on the face of the earth.

What clearer evidence could current Americans need of the subjectivity of race than Franklin's insistence that Germans and Swedes were nonwhite? (Jacobson 1998 , p. 40)

Whereas the immediate excitement about whiteness studies stems from their new way of underscoring the subjectivity of race, the accompanying unease 
relates to the version of that subjectivity that the whiteness studies authors propound. The seminal historical statement on the construction of race, of which the construction of whiteness is a variant, is to be found in Barbara J. Fields's influential essay « Ideology and race in American history » (1982). Noting that " ideas about color, like ideas about anything else, derive their importance, indeed their very definition, from their context », Fields warned against reifying racial " attitudes », which have no meaning aside from their concrete historical setting. " An understanding of how groups of people see other groups in relation to themselves must begin by analyzing the pattern of their social relation ", she explained, " not by enumerating "attitudes" which, endowed with independent life, are supposed to act upon the historical process from outside ». Suggesting that there can be no such thing as a generalized "white " attitude toward " blacks » (or, one might add, toward " whites »), she argued that race is shaped by concrete human interactions, particularly by class relations. Because race is a subjective ideological construct whereas class « can assert itself independently of people's consciousness » - that is, class can be an objective category - « class and race are concepts of a different order; they do not occupy the same analytical space, and thus cannot constitute explanatory alternatives to each other » (Fields 1982, pp. 146, 149, 150).

Fields's formulation of the construction of race frames a set of tricky problems centering on the reality, pervasiveness, and permanence of whiteness and especially its relationship to concrete historical conditions. Scholars approach the problems in different ways. Some explain whiteness as a direct function of dominant economic interests. According to the historian Theodore W. Allen, for example, the " white race » was invented by the " plantation bourgeoisie » in order to facilitate its oppression of African slaves. Similarly, the anthropologist Karen Brodkin maintains that in the United States Jews were treated as racially different so that they could be exploited as industrial laborers. " Initially invented to justify a brutal but profitable regime of slave labor », she explains, « race became the way America organized labor and the explanation it used to justify it as natural ${ }^{12}$.

Leery of an approach that they see as overly deterministic, Jacobson and Roediger - along with many other whiteness studies authors - go to the other extreme, not only denying that race is a direct function of dominant class interest, but coming close to portraying race as a ubiquitous and unchanging transhistorical force rather than a shifting and contingent " construction». Reflecting a broad-based, ongoing shift in the historical profession from social to cultural history, they are more comfortable discussing " tropes » than actual social relations, and they display notable unease about coming to grips with class, interest, and power. Jacobson explains that class has received enough attention from others and that he will therefore emphasize " other areas ». Hale, in her delineation of the " culture of segregation ", almost totally ignores class - indeed, power 
relations of any sort - speaking broadly of the attitudes of " whites ", « southerners », and "Americans » as if these had generalized meaning divorced from their specific environment. Even Roediger, who identifies himself as a Marxist, firmly rejects the view that race is superstructural. Specifically contesting Fields's assertion that whereas race is entirely constructed, class has both objective and subjective components, he maintains that neither race nor class has meaning aside from people's consciousness of them. Roediger recognizes the problem: " To set race within social formations is absolutely necessary », he writes, « but to reduce race to class is damaging ». True enough, but in positing race and class as equal - and equally constructed - he backs away from examining race « within social formations » and implies that it has intrinsic meaning apart from specific relations of power ${ }^{13}$.

In short, there is a persistent dualism evident in the work of the best whiteness studies authors. At times, race - and more specifically, whiteness - is treated as an artificial construct with no real meaning aside from its particular social setting; at other times it becomes not only real, but omnipresent and unchanging, deserving attention as an independent force. Race appears as both real and unreal, transitory and permanent, ubiquitous and invisible, everywhere and nowhere, everything and nothing. Many of the whiteness studies authors are aware of this dualism and see it as a reflection of a similar dualism in whiteness itself. "Whiteness is everywhere in U.S. culture », notes one, « but it is very hard to see »; « no one at this point really knows exactly what whiteness is », assert two others, even while discussing its pervasiveness. Observing that the white women she interviewed in California did not feel white so much as « normal » or " regular », the sociologist Ruth Frankenberg calls whiteness « an unmarked marker of others' differentness "; just as many people consider their own speech - unlike the accents they hear all around them - standard, whiteness, even while omnipresent, appears unrecognized except as that which is normal. Jacobson apologizes for not putting " race », " white », and other racial « fabrications » in quotation marks but then asserts that « race and races are American history...; to write about race in American culture is to exclude virtually nothing ". The all-and-nothing character of race challenges all the whiteness studies authors, who must decide whether race is - and explains - everything or nothing ${ }^{14}$.

The central question one must confront in evaluating whiteness studies is the salience of whiteness as an explanation for exploitation, injustice, and, more generally, the American past. In addressing that question, the matter of context becomes crucial. Simply put, in making whiteness omnipresent, whiteness studies authors risk losing sight of contextual variations and thereby undermining the very understanding of race and whiteness as socially constructed.

Nonhistorians are particularly prone to deprive whiteness of historical context. As Roediger notes in pointing to " tensions » within the field of white- 
ness studies, « much cultural studies work in the area lacks historical grounding and ignores or misconceives the emphasis on class relations common among historians of whiteness ». In Scenes of subjection, for example, the literary scholar Saidiya V. Hartman portrays white racism as a constant unaffected by any change in the social order, including " the nonevent of emancipation ", and sees virtually everything done to or for African Americans as an expression of that racism. A similar inattention to context underlies Brodkin's attribution of American prejudice against Jews (their " temporary darkening ») to the desire to exploit them as industrial laborers, without bothering to place that prejudice in the framework of the long European history of anti-Semitism - an anti-Semitism that was not always rooted in economic interest and did not always require that Jews be seen as nonwhite. Writing as if racism were a uniquely American illness, the American studies scholar George Lipsitz muses that « it must be the content of our character » 15 .

But inattention to context bedevils many of the historians as well. In White women's rights, for example, one of the few historical works to examine the way whiteness shaped the experiences and behavior of women, Louise Michele Newman too often strays from her intriguing exploration of the impact on feminism of a particular form of evolutionary racism and generalizes about the views of " white women ", who resisted patriarchy for themselves but sought to impose it on « inferior » races. Pushing far beyond the sensible observation that most white feminists shared the racial prejudices common among whites in the late nineteenth and early twentieth centuries, she understates the range and complexity of feminist thought and argues that racism was « an integral, constitutive element » of feminism itself, or as she puts it, « feminism developed... as a racialized theory of gender oppression » (Newman 1999, esp. 8, 183, 21).

Such overgeneralization is especially prevalent among historians who rely heavily on image, representation, and literary depiction. Grace Elizabeth Hale's densely written but fascinating book, Making whiteness, has the rare advantage among whiteness studies works of dealing with that part of the country where race has most pervasively shaped social relations: the South. But Hale loses much of that advantage by paying virtually no attention to social relations and confusing what is southern with what is more generally American until the reader is unsure whether she is describing southern whiteness or American whiteness, or whether she thinks that it does not make any difference. The South, she concludes, « lies not south of anywhere but inside us ». Never really explaining what she means by « whiteness » (which at times she equates with segregation) or whose interests it served, she is on equally slippery ground in confronting chronological context. "Whites [all? most? some?] created the culture of segregation ", she proclaims, " in large part to counter black success ». This thesis is perfectly plausible, if undemonstrated. But in arguing that the myths of the happy slave and of criminal Reconstruction were products of the late-nineteenth-century 
imagination, Hale largely ignores earlier versions of those myths propounded by protagonists in the struggles over slavery and Reconstruction; the arguments that she treats as new were appropriations and modifications of arguments previously forged in real social relations. Indiscriminately mixing fiction and nonfiction as documentation, she confuses description (at which she is very good) with explanation and almost totally ignores interest and politics in her delineation of the « making » of whiteness ${ }^{16}$.

Although Jacobson pays more attention to contextual variation, he too can paint with a very broad brush, in the process placing a heavy explanatory burden - I believe too heavy - on whiteness. His focus on image and representation makes it difficult to judge the prevalence of particular ideas, because in quoting extensively from racist stereotypes, he makes no effort to give equal time to the opponents of such views. Brilliantly exploring racial depictions of diverse immigrant groups that Americans would later consider ethnic rather than racial and thereby showing the subjective character of race, he too often blurs a crucial distinction between " race " on the one hand and " nation ", " nationality ", and « ethnicity » on the other. For if both race and nation are constructed (imagined) communities, they are differently constructed: whereas race implies inherent, immutable characteristics, national and ethnic identity can be conceived of as inherent but need not be. Throughout much of American history, Americans have promiscuously combined racial and nonracial thinking in differentiating among groups; sometimes they assumed that differences were inherent, sometimes not, and often they failed to articulate clear positions on the question (no doubt because they had not formulated such positions). Jacobson himself notes in passing that discrimination was not always based on color or race - « The loudest voices in the organized nativism of the 1840s and 1850s harped upon matters of Catholicism and economics, not race »- but he tends to assume the biological nature of arguments that could as easily be interpreted as cultural. (See, for example, his citation of the assertion in the 1911 publication A dictionary of races or peoples that « the savage manners of the last century are still met with amongst some Serbo-Croatians of today » as evidence for emphasis on the " physical properties » of race) ${ }^{17}$.

The role of whiteness in this process of distinguishing among groups remains murky. On one hand, Jacobson portrays the 1840 s-1920s as a period of " variegated whiteness " in which white Americans saw some whites as whiter than others, warns us not to " reify a monolithic whiteness ", and speaks of a « system of "difference" by which one might be both white and racially distinct from other whites ». On the other, he speaks of the " process by which Celts or Slavs became Caucasians ». The unresolved issue here is the extent to which Americans conceived of whiteness (rather than other criteria such as religion, culture, ethnicity, and class) as the main ingredient separating the civilized from the uncivilized (Jacobson 1998, pp. 6, 14). 
There can be no doubt, for example, that many antebellum Americans viewed the Irish as a degraded and savage people, but whether they saw lack of whiteness as the key source of this inferior status is dubious; to most Americans, for whom Protestantism went hand in hand with both republicanism and Americanism, the Irish immigrants' Catholicism was far more alarming than their color. Indeed, some abolitionists managed to combine a passionate belief in the goodness and intellectual potential of black people with an equally passionate conviction of the unworthiness of the Irish, and in the 1850s many nativists saw little difficulty in moving from the anti-Irish Know-Nothing party into the antislavery Republican party, a trajectory that would have been truly remarkable had their dominant perception of the Irish been that they were nonwhite. And as Jacobson points out, the 1790 law that limited naturalization to " free white persons » " allowed Irish immigrants entrance as "white persons" "; in what sense, then, should one speak of their subsequently " becoming " white? This can make sense if whiteness is to be understood metaphorically, meaning « acceptable », but Jacobson and other whiteness studies authors clearly intend the term to serve as more than a metaphor; indeed, if it is understood only metaphorically, much of their analysis collapses $^{18}$.

The overworking of whiteness is especially noteworthy in the work of David Roediger, for he professes greater interest in specific social relations than many whiteness studies authors. Nevertheless, his argument too often depends on blurring important distinctions among whites, thereby belying the commonality of the " wages of whiteness » he outlines. His starting point is promising: living in a slaveholding republic, white workers in the (northern) United States increasingly defined themselves by what they were not - blacks, slaves. But defining oneself as not-black and as not-slave are not at all the same, and Roediger's fudging on that crucial point is especially striking coming from someone who usually pays such careful attention to language. The "not-slave " formulation led to the elaboration of a "free-labor» ideology that combined an emphasis on the dignity of labor with a condemnation of chattel slavery as the antithesis of free, republican (that is, American) values; the "not-black » variation led to a racist denigration of nonwhites and the insistence that the United States was a « white man's country ». The two views could go together; but often they did not, and Roediger's argument that whiteness was an essential element of free-labor ideology is unpersuasive. If some labor radicals took what amounted to the proslavery position that slaves in the South were better off than " free » white workers in the North, others did not, and the argument in any case rested less on the degree of whiteness than on the degree of exploitation. Similarly, Roediger's thesis that in rejecting the term " servant » in favor of " hired hand " and " help », workingmen were « becoming » white conflates two very different forms of resistance to dependence that could be, but were not always, combined. The uppity domestics who tormented Frances Trollope in Cincinnati expressed little or no concern for 
whiteness as they asserted their American equality, and they contrasted their rights, not with black dependence, but with that stemming from English hierarchy. Responding disdainfully to Trollope's expectation that she would eat in the kitchen, one servant typically « turned up her pretty lip, and said, "I guess that's cause you don't think I'm good enough to eat with you. You'll find that won't do here" " 19 .

The question is not whether white racism was pervasive in antebellum America - it was - but whether it explains as much as Roediger and others maintain. In an argument further developed by Ignatiev, Roediger asserts that « it was by no means clear that the Irish were white ». They present little evidence, however, that most Americans viewed the Irish as nonwhite. (To establish this point one would have to analyze the « racial » thought of Americans about the Irish, a task that neither Roediger nor Ignatiev undertakes.) Indeed, the whiteness studies authors often display a notable lack of precision in asserting the nonwhite status of despised groups. Roediger suggests that Irish whiteness was «by no means clear "; Ignatiev speaks of « strong tendencies... to consign the Irish, if not to the black race, then to an intermediate race located between white and black »; Neil Foley, in discussing prejudice against poor whites in central Texas, proclaims that « not all whites... were equally white » and suggests that landlords felt that their tenants « lacked certain qualities of whiteness »; Brodkin states that « for almost half a century, [Jews] were treated as racially not-quite-white ». What is at issue is not the widespread hostility to and discrimination against the Irish, Jews, poor whites, and multiple other groups, but the salience of whiteness in either explaining or describing such hostility and discrimination. The status of southern poor whites is especially telling, for despite persistent « racial » stereotypes of them as shiftless, slovenly, and degraded, such stereotypes did not usually include denials of their whiteness. Americans have had many ways of looking down on people without questioning their whiteness ${ }^{20}$.

A brief consideration of the ideology of four prominent nineteenth-century Americans - the Confederate vice president Alexander H. Stephens, Illinois's Democratic senator Stephen A. Douglas, Abraham Lincoln, and Ohio's Republican senator Benjamin F. Wade - illustrates the risk of overemphasizing whiteness. Like most white Americans, all four were in some sense committed to whiteness. In his famous speech hailing the secession of the southern states, Stephens boldly identified as the "cornerstone " of the new government « the great truth that the negro is not equal to the white man; that slavery, subordination to the superior race, is his natural and moral condition ». In the LincolnDouglas debates of 1858, Douglas mercilessly denounced his Republican challenger as a supporter of black equality and boasted that « this government was made on the white basis... It was made by white men, for the benefit of white men and their posterity for ever, and I am in favor of confining citizenship to white men ». Lincoln responded that he did not favor " political and social equality 
between the white and black races "; noting the " physical difference » between the races, he proclaimed that « in as much as it becomes a necessity that there must be a difference, $\mathrm{I}$, as well as Judge Douglas, am in favor of the race to which I belong, having the superior position ». Upon his arrival in Washington, DC, in 1851, Wade complained that " the Nigger smell I cannot bear ", adding that the food was « all cooked by Niggers until I can smell and taste the Nigger » ${ }^{21}$.

Yet any treatment of those four men that stopped at their common commitment to whiteness would be so incomplete as to be totally misleading. Stephens was an ardent Confederate whereas the other three were committed Unionists. Their differences on slavery and black rights were even more notable. Stephens was a defender of slavery and black racial subordination. Douglas saw slavery as a minor issue whose fate should be left to local (white) control. Lincoln believed that slavery was morally wrong as well as socially degrading, eschewed the race-baiting that Douglas and many other white Americans took for granted, and in his debate with Douglas immediately qualified his support for white supremacy with the ringing assertion that whether or not "the negro " was equal in all respects, " in the right to eat the bread, without leave of anybody else, which his own hand earns, he is my equal and the equal of Judge Douglas, and the equal of every living man ". Wade was an ardent opponent of slavery, who became one of the most enthusiastic proponents of a radical Reconstruction policy designed to remake the South and provide equal rights for the former slaves, as well as a sturdy champion of the rights of women and of labor. In short, what is most significant about the careers of the four men lies, not in their shared expressions of whiteness, but in the sharply divergent positions they took on the major issues of their era. Whiteness turns out to be a blunt instrument for dissecting the nuances - or even the major outlines - of their political ideology and behavior ${ }^{22}$.

One of the most striking features of many whiteness studies works is their subjective character, their postmodern accentuation of self. Often the authors supplement analysis and prescriptive proposals with personal anecdotes, recollections, and ruminations - sometimes, but by no means always, confined to an introduction or conclusion. George Lipsitz, for example, provides a long personal account beginning with his reaction as a child living in New Jersey to the murder of a civil rights worker in 1963 and moving on to his current determination, as an adult in California, to resist « racist attacks on communities of color » abetted by " the mendacity and meanness of Governor Pete Wilson ». Ruth Frankenberg begins her book with an autobiographical discussion of how as a white feminist she struggled with charges of racism. In detailing how Jews became white, Karen Brodkin not only discusses her own childhood and the question of Jewishness in an autobiographical introduction, but throughout the volume writes explicitly as a Jew (noting, for example, that "prevailing classifications... have sometimes 
assigned us to the white race "). Roediger begins The wages of whiteness with an account of how he came to reject the racism he had taken for granted as a child. " Until very recently ", he observes, " I would have skipped all this autobiographical material, sure that my ideas on race and the white working class grew out of conscious reflection based on historical research. But much of that reflection led back to what my early years might have taught me... My own youthful experiences... could have given me the central themes of this book ${ }^{23}$.

Even when they do not engage in such autobiographical exercises - and historians are usually the most reticent of the whiteness studies authors in this regard - virtually all of these authors display a highly didactic tone and a tendency to blend policy proposals with historical analysis. Of course, they are hardly alone in producing present-minded or partisan work; as Peter Novick and others have shown, even the most avowedly " objective " works of history have been ideologically laden. Few historians have been so eager openly to mix scholarly analysis with prescriptive advice, however, or to proclaim their political goals so bluntly as those engaged in the study of whiteness. Thus, Jacobson, the most restrained of the authors under review, suggests that « perhaps the most far-reaching ambition » of Whiteness of a different color is " to help loosen the grip of race », and Hale, asserting that « integration... is our only future », proposes « a newly imagined integration [that] would incorporate black autonomy, authority, and subjectivity ». Ending The invention of the white race with a hope for the future, Allen declares that « perhaps in the impending renewal of the struggle of the "common people" and the "Titans", the Great Safety Valve of white-skin privileges may finally come to be seen and rejected by laboring-class European-Americans as the incubus that for three centuries has paralyzed their will in defense of their class interests vis-à-vis those of the ruling class $"$. These authors wear their hearts on their sleeves ${ }^{24}$.

Those present-minded concerns help explain why it is in the 1990s that there has been such an explosion of work on whiteness. As in other fields, that work is in part self-propelling: once a significant body of scholarship on a topic appears, it acquires a life of its own. But underlying the new interest in white power, privilege, and identity there is evident an intense discouragement over the persistence of racism, the unexpected renewal of nationalism, and the collapse of progressive movements for social change that characterize the current era. Jacobson points to the " ethnic revival» in America among groups that deny white privilege and see themselves as victims and concludes that « racism now appears not anomalous to the working of American democracy, but fundamental to it ». Noting the « chastened and disspirited mood of contemporary American liberalism ", Roediger observes that « the absence of a liberal labor vote- both because so few workers are now organized and because a majority of those in white households containing a union member have voted for Reagan and Bush over the last three elections - makes prospects for an ongoing mildly progressive, 
class - based alliance inauspicious ». A sense of political disillusionment and a conviction that class-based efforts to remake the world have been tried and found wanting link Roediger's perception of the bleak current situation with his understanding of the past: " the historical record of antiracist achievements of coalitions for economic reform », he laments, "is quite modest ». In whiteness, Roediger and other authors see the latest answer to the old question (and its more modern variants) posed by Werner Sombart in 1906, « Why is there no socialism in the United States? » Only through a confrontation with whiteness, they suggest, can a revitalized American Left emerge ${ }^{25}$.

Because their work is so heavily prescriptive, important clues to the whiteness studies authors' understanding of whiteness emerge from what they suggest should be done about it. Pushing the logic of its constructed nature to its ultimate conclusion are those, Roediger and Ignatiev foremost, who call for the " abolition » of whiteness. Asserting that « whiteness, like royalty, threatens to arrange human society by the rules of animal breeding », Ignatiev and John Garvey, who since 1992 have served as coeditors of the journal Race traitor; proclaim that « the key to solving the social problems of our age is to abolish the white race... Treason to whiteness is loyalty to humanity ". Central to this abolitionist goal is belief in the moral emptiness of whiteness: "There is Italian culture... but there is no "white culture" - unless you mean Wonderbread and television game shows ", pronounces Race traitor: "Whiteness is nothing but the expression of race privilege ». Distinguishing sharply between whiteness and blackness - he capitalizes « Black » and " Blackness » but not « white » and " whiteness »- Roediger agrees with Ignatiev on the emptiness of whiteness: "It is not merely that whiteness is oppressive and false ", he explains; « it is that whiteness is nothing but oppressive and false ». Noting that « we speak of African American culture and community, and rightly so », Roediger exhibits some momentary unease at celebrating " Blackness » while condemning " whiteness » - « neither whiteness nor Blackness is a scientific (or natural) racial category 》- but in the end insists that « the former is infinitely more false, and precisely because of that falsity, more dangerous, than the latter ». As a result, even though all race is socially constructed, the overriding need is « to attack whiteness as a destructive ideology rather than to attack the concept of race abstractly ». Hale agrees. "Would America be American without its white people? » she asks at the end of Making whiteness. "No. It would be something better, the fulfillment of what we postpone by calling a dream ${ }^{26}$.

Precisely what " abolishing whiteness " means is open to question, however, in part because the meaning of "whiteness » is similarly open. Ignatiev argues that the word « racism » is « useless » because it has too many meanings, but one could suggest that there is also a hierarchy of meanings for abolishing whiteness (based on a hierarchy of meanings for whiteness itself) from rejecting white privilege (or racism), to rejecting white « identity » (that it matters whether one is 
white), to claiming that there is no such thing as being white, to seeing whiteness as an evil to be combated. On a practical level, there is a need to be clear on what one is being asked to reject (Ignatiev 1995, p. 178).

There is also a practical political issue that, given the policy concerns of so many of the whiteness studies authors, demands consideration. In the revised version of The wages of whiteness, Roediger expresses dismay at charges that he is " down on white people » and counters that « there is, of course, not the slightest animosity toward people who are categorized as white in wages of whiteness ». True enough, but there is a thin line between saying that whiteness is evil and saying that whites are evil, and it is easy to see how Roediger and Ignatiev can be misunderstood on this score. They make a legitimate distinction between black and white as nonparallel terms, pointing out that there is a black (and an Asian American and an Italian American) culture but not a white culture. This argument holds, but only up to a point: there is no one black (or Asian American) culture, not every black person is culturally " black », and as Jacobson shows, the distinction between cultural and racial definitions of ethnic identity is so tenuous that at times it appears nonexistent. Equally important, there is a serious political problem with first proclaiming that race is arbitrary and then arguing that to identify as white is reprehensible but to identify as black is virtuous. Indeed, such an argument is less likely to dampen white racism than to fuel a sense of white ethnic identity - and victimhood - of the type that the journalist Tony Horwitz describes so graphically in his recent book, Confederates in the attic (Roediger 1991, p. 186; Horwitz 1998).

The most obvious solution to this problem is to challenge the desirability of any racial identification, black as well as white. The British sociologist Paul Gilroy suggests that it is time to abolish "race » itself, not just whiteness, and the historian Mia Bay, raising the question of " anti-racist racism ", suggests that " the concept of race is virtually inseparable from the idea of a hierarchy among the races $\gg{ }^{27}$. Many of the nonhistorian whiteness studies authors, however, reject the notion of abolishing whiteness in favor, not of a more general abolition of racial identification, but of the substitution of a new, "good » whiteness for the old racist version. "If whiteness is emptied of any content other than that which is associated with racism or capitalism », suggests Frankenberg, "this leaves progressive whites apparently without a genealogy ». George Yúdice, who teaches cultural studies, agrees that Whites need some form of white ethnic identification. Suggesting that the abolitionist position "seems more wishful thinking than carefully thought-out strategy", he argues that "declaring nonwhiteness... is not really an option for many Whites in precarious positions » and proposes instead "a rearticulation of whiteness » based on "imagining nonracist and nonnormativist ways of being white». Warning of conservative efforts to capitalize on feelings of white victimhood, Joe L. Kincheloe and Shirley R. Steinberg, scholars whose interests span education and cultural 
studies, assert « the necessity of creating a positive, proud, attractive, antiracist white identity ${ }^{28}$.

If it is easy to see why many of these scholars are uneasy about asking whites to renounce their whiteness while celebrating everyone else's multicultural ethnic diversity, there are reasons why encouraging people to identify with a reconfigured "good" whiteness seems even more problematical. To begin with, this approach implies that racism stems primarily from misunderstanding and ignorance, and that the solution to it therefore lies more in changing minds than in confronting interests. Equally important, because positing the goal of creating a new and better whiteness implicitly accepts the legitimacy of racial identification, it comes close to vitiating race's constructed character itself. And finally, since, as Bay points out, every racial identification implies a negative judgment of outsiders - feeling that it is " good » to be white (or black or Asian) inevitably implies there is something less good about being non-white (or non-black or nonAsian) - encouraging a renewed sense of whiteness is unlikely to promote a more equitable or harmonious social order. In short, neither the goal of abolishing whiteness alone nor that of promoting a more positive whiteness seems especially promising. The different meanings of whiteness and its abolition are once again pertinent. Repudiating white privilege is one thing, but it is hard to imagine a successful assault on whiteness in the sense of people's self-identification as white except within the broader context of breaking down racial identification in general.

Because the whiteness literature is so diverse, summing up its contributions is by no means easy. Nevertheless, several conclusions seem justified. First, this rapidly growing body of works has provided insights that collectively help us refine our interpretation of race in America and at large. These works have built on and solidified our understanding of how race is constructed. At their best, they have underscored the historical process of racial construction, showing how assumptions about race and races have changed over time and exploring human agency in the making of race. They have reminded us that race making applies to whites as well as nonwhites; in Neil Foley's words, " whites are raced » (Foley 1997, p. 11). They have demonstrated that racial categories are not always constructed as binary opposites, although that insight is partially obscured in the effort to portray nonprivileged groups as of necessity nonwhite - that is, to fit complex racial thought into a binary mold and make whiteness alone the defining racial concept. And perhaps most important, they have found a new way to emphasize the absurdity - and oppressiveness - of race as a system for categorizing humans.

The contribution of whiteness studies to our understanding of actual social relations is less clear. In viewing whiteness as an independent category, many whiteness studies authors come close to reifying it and thereby losing sight of its 
constructed nature; in assigning whiteness such all-encompassing power; they tend to ignore other forms of oppression, exploitation, and inequality; and in focusing so heavily on representations of whiteness, they too often ignore the lived experiences - as well as the perceptions - of those perceived as nonwhite or « not quite » white. In moving beyond a binary treatment of race, it is important to keep in mind that African Americans' experience of race differed qualitatively from that of other ethnic groups because of the involuntary nature of their immigration, their enslavement, and the unparalleled virulence of the racism directed against them. Applied properly, a multiracial approach can underscore the distinctiveness of African Americans' racial history, but without attention to concrete social conditions that distinctiveness is more likely to be obscured than clarified.

In short, we are back to the question of context. One of the most striking features of the whiteness studies works is their assumption - sometimes asserted and sometimes unspoken - that the racism they describe is uniquely American and that American whiteness can be understood in isolation, without considering anything abroad. In this respect, they differ markedly from the best of the « old » works on race; in Race (1963), for example, Thomas F. Gossett placed American racial thought in European context and portrayed American racism as a particular manifestation of a broader intellectual phenomenon. Despite Roediger's persuasive argument that the virulence of white racial identification stemmed from the particular circumstances of living in a slaveholding republic, white racism has by no means been a peculiarly American phenomenon, and grounding the study of American whiteness in broader international context can help accentuate the particular nature and features of race making in the United States. In an account that should sound familiar to students of the nineteenth-century United States, Sue Peabody argues that eighteenth-century France produced antislavery sentiment and racism-both « derived from the same ideological origin: the tension between colonial slavery and the cult of liberty in France ». The current debate over the European experience of empire and the role of race in constructing the colonial « other » and work on race and racism in places as diverse as modern England, eighteenth-century France, and twentieth-century French West Africa are surely pertinent to the study of whiteness in America, as is the long European history of racial thought and anti-semitism ${ }^{29}$.

Historical works on whiteness could also benefit from more historiographical context. Before whiteness studies, historians of race debated the emergence and evolution of white racism in the southern colonies, suggested that the American Revolution promoted a sharp increase in white racial consciousness, and studied the rise of segregation in the post-Civil War South ${ }^{30}$. They, too, argued that racial understanding and categorization evolved - that is, that race was " constructed " (although they did not use the term) - and noted, in a manner foreshadowing Jacobson's treatment, the rise of racial prejudice against immigrants in the second half of the nineteenth century. " By a little judicious tampering, the 
historians and political scientists could adapt racial theory to the needs of the moment », noted Gossett. " The fact that race has no precise meaning has made it a powerful tool for the most diverse purposes » (Gossett 1997, p. 118). In some ways, what is newest in the historical works on whiteness is a new language, a new way of saying something that is not all that different from what many historians have been saying for some time. Indeed, despite appearances, whiteness studies represent less a radical new departure than an evolution of a historical scholarship that has long been preoccupied with the changing ways of making race. The focus on whiteness represents a new way of addressing old questions, but the central concern of the new scholarship - how, under diverse conditions, Americans conceptualized and reconceptualized race - is very much in line with the historical literature of the past four decades ${ }^{31}$.

As it builds on the old history of race, the field of whiteness studies has - despite its current limitations - considerable unfulfilled potential. It is not surprising that authors in the field have sometimes claimed more for whiteness than the evidence will support or that their work is often characterized more by boldness than by finesse, for such is typically the nature of new disciplines or approaches. Many of the same strengths and weaknesses can be noted in works that burst upon the historical profession in the 1970s emphasizing « the » slave community and " the » sisterhood of women ${ }^{32}$. Indeed, just as later historians built upon and refined those exciting but overargued works, one might suggest that whiteness studies authors in the future will reach in new directions even as they continue to fill in and revise the outlines set by their predecessors. Although it would be presumptuous to predict the exact nature of this future scholarship, I would hope its characteristics would include greater attention to historical and geographical context, more precision in delineating the multiple meanings of " whiteness », continued effort to move beyond a strictly binary approach to race even while emphasizing the distinctive ways African Americans experienced race and racism, continued exploration of the complex relationship between race and nation, closer consideration of the South's role in shaping American notions of race, more sustained treatment of actual lived relations, and more inclusive examination of the way nonwhites and whites-in-the-making have perceived whiteness (and nonwhiteness) ${ }^{33}$. In its prescriptive mode, whiteness studies scholarship will need to confront the disagreements dividing those who would abolish whiteness, those who would reconfigure whiteness, and those who would abolish race in general and to confront whether in making pronouncements about such goals they are not - like King Canute commanding the waters to stopconsiderably overestimating their own influence.

The accelerating pace of publications on whiteness suggests that we will be seeing a great deal more work in this area over the coming years. Perhaps it is not too much to hope that ten years from now, we will be able to conclude that it was in their second decade that whiteness studies really came of age. 


\section{Notes}

I would like to thank Margaret L. Andersen, Anne M. Boylan, Lori Ginzberg, and the graduate students in my advanced seminar (Tracey Birdwell, Evelyn Causey, John Davies, Karen Ryder, and Christine Sears) for helpful comments on an earlier draft of this essay.

1. This first part was originally published in The Journal of American History, 89 (June 2002), pp. 154-173, and appears here unrevised except for minor corrections and changes in format. I am grateful to the Journal of American History for permission to reprint it.

2. DELCAT search, <http://www.lib.udel.edu/databases/delcat.html> (Sept. 26, 2001). Of the 51 titles, 3 have publication dates before 1990, 3 from 1990 to 1993, 12 from 1994 to 1997, and 33 from 1998 to September 2001. The figures do not represent a precise and all-inclusive total of whiteness studies books: a few, including the oldest (a 1943 work on visual perception), are unrelated to the field, and other whiteness studies books are not on the list because the word « whiteness » does not appear in their titles. Whiteness articles are vastly more numerous: an online search of Expanded Academic ASAP (published by Gale Group) yielded 373 references to works published since 1985 containing « whiteness $"$ in their titles, citations, or abstracts.

3. Foley (1997); Ignatiev (1995); Hale (1998); Lipsitz (1998); Delgado and Stefancic (1997).

4. See, for example, Brown (1996); Johnson (1999); Gross (2000); and Nelson (2001).

5. Roediger (1991); Jacobson (1998). See also the revised edition of Roediger's Wages (1999b, pp. 185-189, 190), which reprints the original edition with the original pagination, adding an « Afterword " and a list of " Selected Critical Writings ».

6. Extensive scholarly commentary on the whiteness studies literature is just beginning to appear. A symposium that appeared too late to consult in preparation for this article includes a sharply critical essay by Eric Arnesen (2001) with responses (also mostly critical) by six historians. For a perceptive evaluation that focuses on works by nonhistorians, see Andersen (2003).

7. Roediger (1999b, p. 134); Saxton (1990); Ignatiev (1995).

8. See also Foley (1997). For the suggestion that « adding Indians to the picture changes our view of the history of race in the South ", see Gross (2001, p. 681). Roediger has recently praised the effort to move beyond the black/white racial framework of The wages of whiteness; see Roediger (1999a, esp. 592-600).

9. Jacobson (1998, p. 18); Hale (1998). In criticizing Roediger for focusing too heavily on economics, Jacobson also targets Theodore W. Allen's account of the rise of white racial consciousness in the English mainland American colonies (Allen 1994-1997).

10. Thompson (1975, p. 325); Gould (1981, p. 20). See also Graves (2001). For a prominent historian's recent assertion that "historical construction » of race is more accurate than "social construction ", see Berlin (1998, p. 1).

11. For the first story, see Fields (1982, p. 146); for the second, see Montgomery (2000, p. 15).

12. Allen (1994-1997, vol. II, p. 97); Brodkin (1998, p. 75). See also Saxton (1990).

13. Jacobson (1998, p. 21); Hale (1998); Roediger (1991, p. 8). For Roediger's discomfort with Barbara J. Fields's formulation of the relationship between race and class, see Roediger (1994, pp. 25-27). Iver Bernstein (1992, p. 1120) has suggested that Roediger's approach « takes its cue from the recent critical writings of George $M$. Fredrickson urging greater consideration of race as an independent psychological category of analysis and, like Fredrickson's work, calls to mind W. E. B. Du Bois's dissatisfaction with the materialist treatment of race by American Marxists during the 1930s ».

14. Lipsitz (1998, p. 1); Kincheloe and Steinberg (1998, p. 4); Frankenberg (1993, p. 198); Jacobson (1998, pp. ix-x, 11). One of the first whiteness studies works to note this " everything-and-nothing quality » was an analysis of film; see Dyer (1988, p. 64).

15. Roediger (1999a, p. 580); Hartman (1997, p. 116); Brodkin (1998, p. 76); Lipsitz (1998, p. 213). «Some Europeans who believed in race classified Jews as whites or even Aryans, even if for the most part they were considered the enemy », according to Mosse (1978, p. xii). In discussing " tensions » 
within whiteness studies, Roediger (ibid., p. 580) also points to historians who « disdain cultural studies approaches, and even inquiries into race and cultural representation more generally, as ethereal and frivolous ".

16. Hale (1998, pp. $295,21,43-84$, passim). For a study that approaches the making of segregation and whiteness in a southern state historically, see Dailey (2000, esp. 132-154). See also Gilmore (1996).

17. Jacobson (1998b, pp. 69, 79). For a persuasive distinction between a "civic" American nationalism rooted in equality and universalism and a "racial » nationalism that assumes inherent national characteristics, see Gerstle (2001). For nation as « imagined community », see Anderson (1991). On the close historical links between race and nation (and between racism and nationalism), see also Holt (2000, pp. 41-56); Balibar and Wallerstein (1991); and Gross (2001, p. 681). For an interesting synthetic study of American attitudes toward foreigners that recognizes but at times fudges the distinction between racial and culture " difference » arguments, see Jacobson (2000). The promiscuous mixture of racial and nonracial depictions of " nationalities » has a parallel in the mixture of racial and nonracial arguments in defense of slavery; see Kolchin (1993, pp. 184-197).

18. Jacobson (1998, p. 51). On the anti-Catholic heart of American nativism, see Billington (1938). On the « Paddy » stereotype, see Knobel (1986). On the lives of Irish immigrants, see Miller (1985) and Handlin (1991). On the antislavery character of northern Know-Nothingism, see Anbinder (1992).

19. Roediger (1991, p. 49); Trollope (1993 [1832], p. 33). The essential starting point on free-labor thought is Foner (1970).

20. Roediger (1991, p. 134); Ignatiev (1995, p. 76); Foley (1997, pp. 5, 70); Brodkin (1998, p. 56). For an antebellum view of poor whites, see Hundley (1860); for a historical study, see Bolton (1994). A powerful English " racial » prejudice against the Irish existed in the sixteenth and seventeenth centuries, in a world far removed from a slaveholding republic; see Canny (1973, pp. 575-598) and Brown (1996, pp. 33-37).

21. Gienapp (2001, pp. 71-72); Delbanco (1992, pp. 107, 115); Trefousse (1963, p. 311).

22. Delbanco (1992, p. 115). For a nuanced view of the antebellum Republicans and race, see Foner (1970, pp. 261-300).

23. Lipsitz (1998, pp. viii-xx, esp. xviii); Frankenberg (1993, p. 205); Brodkin (1998, p. 1); Roediger (1991, pp. 3-5, esp. 5). For highly personal autobiographical musings, see Berger (1999). See also Foley (1997, pp. xiii-xiv); many of the essays in Cuomo and Hall (1999); and those in Kincheloe et al. (1998).

24. Jacobson (1998, p. 10); Hale (1998, pp. 11, 296); Allen (1994-1997, vol. II, p. 259). See Novick (1998).

25. Jacobson (1998, p. 12); Roediger (1994, pp. 7-8); Sombart (1976 [1906]).

26. Ignatiev and Garvey (1996, pp. 2, 10, 288-289). This volume reprints Race traitor's first five issues, dating from 1992 to 1996. Roediger (1994, pp. 13, 12, 3); Hale (1998, p. 296).

27. Gilroy (2000); Bay (2000, pp. 224, 225). Thomas C. Holt (2000, p. 122), by contrast, calls on African Americans both to embrace and to transcend their blackness, noting that « there is a difference between being nourished by our history and being consumed by it 1 .

28. Frankenberg (1993, p. 232); Yúdice (1995, pp. 271, 261, 259); Kincheloe and Steinberg, (1998, p. 12). Nelson M. Rodriguez (1998, pp. 33, 34) notes that it is "difficult " to say " what would constitute a [positive] pedagogy of whiteness » but warns that « asking white students to renounce their whiteness in some total sense is doomed for failure ».

29. Gossett (1997); Peabody (1996, p. 71); Said (1978); Cannadine (2001); Gilroy (1991); White (1999, esp. 93-123); Alexander and Halpern (2000); Mosse (1978).

30. See, inter alia, Handlin Oscar and Mary (1950); Jordan (1968); Breen (1973); Morgan (1975); Vaughan (1989); Robinson (1971); MacLeod (1975); Stanton (1960); Fredrickson (1971); Woodward (1955); Rabinowitz (1978); and Williamson (1984).

31. I am not the first to make this suggestion. See Gerber (1999, p. 436); and David W. Stowe (1999a; 1999b, p. 1359).

32. For historiographical treatment of these subjects, see Kolchin (1983; 1985), Parish (1989, esp. 64-96); Hewitt (1985), Kerber (1988), and Meyerowitz (1992). 
33. For writings by African Americans on whites and whiteness, see Roediger (1998). There is considerable disagreement over black perceptions of whiteness. The poet bell hooks, for example (1992, p. 341), generalizes (on the basis of childhood recollections) that " white people were regarded as terrorists ", whereas the historian Mia Bay (2000, pp. 168, 226-227), noting that " black folk culture challenged racial stereotypes rather than reversing them ", suggests that the black masses rejected racial categorization and recognized white variability far more than intellectuals did.

\section{REFERENCES CITED}

Alexander Peter and Rick Halpern (eds)

2000 Racializing class, classifying race: labour and difference in Britain, the USA, and Africa, St. Martin's Press, New York.

ALLen Theodore W.

1994-1997 The invention of the white race, Verso, New York, 2 vols.

ANBINDER Tyler

1992 Nativism and slavery: the northern Know Nothings and the politics of the 1850 s, Oxford University Press, New York.

ANDERSEN Margaret L.

2003 "Whitewashing race: a critical review essay on whiteness ", in Ashley W. Doane and Eduardo Bonilla-Silva (eds), White out: the continuing significance of racism, pp. 21-34, Routledge, New York.

ANDERSON Benedict

$1991 \quad$ Imagined communities: reflections on the origin and spread of nationalism, Verso, New York.

\section{ARNESEN Eric}

2001 "Scholarly controversy: whiteness and the historians' imagination », International labor and working-class history, 60 (Fall), pp. 1-92.

BAY Mia

2000 The white image in the black mind: African-American ideas about white people, 1830-1925, Oxford University Press, New York.

BaLIBAR Etienne and Immanuel WaLLERSTEIN (eds)

1991 Race, nation, class: ambiguous identities, Verso, London.

BERgER Maurice

1999 White lies: race and the myth of whiteness, Farrar, Straus Giroux, New York.

BERNSTEIN Iver

1992 "Review of The wages of whiteness by David R. Roediger », Journal of American History, 79, p. 1120.

BERLIN Ira

1998 Many thousands gone: the first two centuries of slavery in North America, Harvard University Press, Cambridge, Mass. 
BiLlington Ray Allen

1938 The Protestant crusade, 1800-1860: a study of the origins of American nativism, Macmillan, New York.

Bolton Charles C.

1994 Poor whites of the antebellum South: tenants and laborers in Central North Carolina and Northeast Mississippi, Duke University Press, Durham.

BREen Timothy $\mathrm{H}$.

1973 « A changing labor force and race relations in Virginia, 1660-1710 », Journal of Social History, 7, pp. 3-25

BRODKIN Karen

1998 How Jews became white folks and what that says about race in America, Rutgers University Press, New Brunswick.

Brown Kathleen M.

1996 Good wives, nasty wenches, and anxious patriarchs: gender, race, and power in colonial Virginia, University of North Carolina Press, Chapel Hill.

CANNAdine David

2001 Ornamentalism: how the British saw their empire, Oxford University Press, New York.

CANNY Nicholas P.

1973 "The ideology of English colonization: from Ireland to America », William and Mary Quarterly, 30, pp. 575-598.

Cuomo Chris J. and Kim Q. HaLl (eds)

1999 Whiteness: feminist philosophical reflections, Rowman and Littlefield, Lanham.

Dailey Jane

2000 Before Jim Crow: the politics of race in postemancipation Virginia, University of North Carolina Press, Chapel Hill.

Delbanco Andrew (ed.)

1992 The portable Abraham Lincoln, Penguin, New York.

Delgado Richard and Jean SteFancic (eds)

1997 Critical white studies: looking behind the mirror, Temple University Press, Philadelphia.

DYER Richard

1988 «White», Screen, 29 (Autumn).

FIELDS Barbara J.

1982 "Ideology and race in American history ", in J. Morgan Kousser and James M. McPherson (eds), Region, race, and reconstruction: essays in honor of C. Vann Woodward, pp. 143-177, Oxford University Press, New York.

FoLey Neil

1997 The white scourge: Mexicans, blacks, and poor whites in Texas cotton culture, University of California Press, Berkeley. 
FONER Eric

1970 Free soil, free labor, free men: the ideology' of the Republican party before the Civil War, Oxford University Press, New York.

FRANKENBERG Ruth

1993 White women, race matters: the social construction of whiteness, University of Minnesota Press, Minneapolis.

FREDRICKSON George M.

1971 The black image in the white mind: the debate on Afro-American character and destiny, 1817-1914, Harper and Row, New York.

Gerber David A.

1999 "Review of Whiteness of a different color by Matthew Frye Jacobson ", Reviews in American History, 27, pp. 437-443.

\section{Gerstle Gary}

2001 American crucible: race and the nation in the twentieth century, Princeton University Press, Princeton.

GienAPp William E. (ed.)

2001 The Civil War and reconstruction: a documentary collection, Norton, New York.

\section{GILMORE Glenda Elizabeth}

1996 Gender and Jim Crow: women and the politics of white supremacy in North Carolina, 1896-1920, University of North Carolina Press, Chapel Hill.

\section{GiLroy Paul}

1991 "There ain't no black in the Union Jack »: the cultural politics of race and nation, University of Chicago Press, Chicago [1987].

2000 Against race: imagining political culture beyond the color line, Harvard University Press, Cambridge, Mass.

GouLd Stephen Jay

1981 The mismeasure of man, Norton, New York, 1981.

Gossett Thomas F.

1997 Race: the history of an idea in America, Oxford University Press, New York [1963].

Graves Joseph L. Jr.

2001 The emperor's new clothes: biological theories of race at the millennium, Rutgers University Press, New Brunswick.

\section{Gross Ariela J.}

2000 Double character: slavery and mastery in the antebellum southern courtroom, Princeton University Press, Princeton.

2001 "Beyond black and white: cultural approaches to race and slavery », Columbia Law Review, 101 (April), pp. 640-689. 
Hale Grace Elizabeth

1998 Making whiteness: the culture of segregation in the South, 1890-1940, Pantheon, New York.

\section{HANDLIN Oscar}

1991 Boston's immigrants: a study in acculturation, Harvard University Press, Cambridge, Mass [1941].

Handlin Oscar and Mary F. HandLin

1950 "Origins of the southern labor system », William and Mary Quarterly, 7, pp. 199-222.

Hartman Saidiya V.

1997 Scenes of subjection: terror, slavery, and self-making in nineteenth-century America, Oxford University Press, New York.

Hewitr Nancy A.

1985 "Beyond the search for sisterhood: American women's history in the 1980 s ", Social History, 10, pp. 299-321.

Holt Thomas C.

2000 The problem of race in the twenty-first century, Harvard University Press, Cambridge, Mass.

HOOKS BELL

1992 "Representing whiteness in the black imagination », in Lawrence Grossberg, Cary Nelson, and Paul A. Treichler (eds), Cultural Studies, Routledge, New York, pp. 338-342.

Horwitz Tony

1998 Confederates in the attic: dispatches from the unfinished civil war, Pantheon, New York.

Hundley Daniel R.

1860 Social relations in our southern states, Henry B. Price, New York.

IGNATIEv Noel

1995 How the Irish became white, Routledge, New York.

IGNATIEv Noel and John GARveY (eds)

1996 Race traitor, Routledge, New York.

JACOBSON Matthew Frye

1998 Whiteness of a different color: European immigrants and the alchemy of race, Harvard, Cambridge, Mass.

2000 Barbarian virtues: The United States encounters foreign peoples at home and abroad, 1876-1917, Hill and Wang, New York.

JoHNSON Walter

1999 Soul by soul: life inside the antebellum slave market, Harvard University Press, Cambridge, Mass. 
JORDAN Winthrop D.

1968 White over black: American attitudes toward the Negro, 1550-1812, University of North Carolina Press, Chapel Hill.

KERBER Linda $\mathrm{K}$.

1988 "Separate spheres, female worlds, women's place: the rhetoric of women's history ", Journal of American History, 75, pp. 9-39.

KinCHELOE Joe L. et al. (eds)

1998 White reign: deploying whiteness in America, St. Martin's Press, New York.

Kincheloe Joe L. and Shirley R. Steinberg

1998 "Addressing the crisis of whiteness: reconfiguring white identity in a pedagogy of whiteness ", in Joe L. Kincheloe et al. (eds), White reign: deploying whiteness in America, pp. 3-29, St. Martin's Press, New York.

KNoBel Dale T.

1986 Paddy and the republic: ethicity and nationality in antebellum America, Weslyan University Press, Middletown.

\section{Kolchin Peter}

1983 "Reevaluating the antebellum slave community: a comparative perspective », Journal of American History, 70, pp. 579-601.

1985 "American historians and antebellum southern slavery, 1959-1984 ", in William J. Cooper Jr., Michael F. Holt and John McCardell (eds), A master's due: essays in honor of David Herbert Donald, Louisiana State University Press, Baton Rouge, pp. 87-111.

1993 American slavery, 1619-1877, Hill and Wang, New York.

LIPSITZ George

1998 The possessive investment in whiteness: how white people profit from identity politics, Temple University Press, Philadelphia.

MACLEOD Duncan J.

1975 Slavery, race, and the American revolution, Cambridge University Press, Cambridge UK.

\section{MEyerowitz Joanne}

1992 "American women's history: the fall of women's culture ", Canadian Review of American Studies (special issue 1), pp. 27-52.

\section{Miller Kerby A.}

1985 Emigrants and exiles: Ireland and the Irish exodus to North America, Oxford University Press, New York.

\section{Montgomery David}

2000 " Empire, race, and working-class mobilizations », in Peter Alexander and Rick Halpern (eds), Racializing class, classifying race: labour and difference in Britain, the USA, and Africa, pp. 1-23, St. Martin's Press, New York.

Morgan Edmund S.

1975 American slavery, American freedom: the ordeal of colonial Virginia, Norton, New York. 
Mosse George L.

1978 Toward the final solution: a history of European racism, H. Fertig, New York.

NeLson Bruce

2001 Divided we stand: American workers and the struggle for black equality, Princeton University Press, Princeton.

Newman Louise Michele

1999 White women's rights: the racial origins of feminism in the United States, Oxford University Press, New York.

Novick Peter

1998 That noble dream: the "objectivity question" and the American historical profession, Cambridge University Press, Cambridge UK.

PARISH Peter J.

1989 Slavery: history and historians, Harper and Row, New York.

Peabody Sue

1996 "There are no slaves in France 》: the political culture of race and slavery in the ancien regime, Oxford University Press, New York.

RABINOWITZ Howard N.

1978 Race relations in the urban South, 1865-1890, Oxford University Press, New York.

RoBINSON Donald L.

1971 Slavery in the structure of American politics, 1765-1820, Harcourt Brace Jovanovich, New York.

Rodriguez Nelson M.

1998 "Emptying the content of whiteness: toward an understanding of the relation between whiteness and pedagogy ", in Joe L. Kincheloe et al. (eds), White reign: deploying whiteness in America, pp. 31-62, St. Martin's Press, New York.

\section{Roediger David R.}

1991 The wages of whiteness: race and the making of the American working class, Verso, New York.

1994 Towards the abolition of whiteness: essays on race, politics, and working class history, Verso, New York.

1999a "The pursuit of whiteness: property, terror, and expansion, 1790-1860 ", Journal of the Early Republic, 19, pp. 579-600.

1999b The wages of whiteness: race and the making of the American working class, Verso, New York.

RoEDiger David R. (ed.)

1998 Black on white: black writers on what it means to be white, Schocken Books, New York.

SAID Edward W.

1978 Orientalism, Pantheon, New York. 
SAxton Alexander

1990 The rise and fall of the white republic: class politics and mass culture in nineteenth-century America, Verso, New York.

SOMBart Werner

1976 Why is there no socialism in the United States? trans. Patricia M. Hocking and C. T. Husbands, International Arts and Sciences Press, White Plains [1906].

STANTON William

1960 The leopard's spots: scientific attitudes toward race in America, 1815-1959, University of Chicago Press, Chicago.

Stowe David W.

1999 "Review of Whiteness of a different color by Matthew Frye Jacobson and The possessive investment in whiteness by George Lipsitz ", Journal of American History, 86, pp. 1358-1359.

Thompson Edgar T.

1975 Plantation societies, race relations, and the South: the regimentation of populations, Duke University Press, Durham.

Trefousse Hans L.

1963 Benjamin Franklin Wade: radical Republican from Ohio, Twayne Publishers, New York.

Trollope Frances

1993 Domestic manners of the Americans, ed. John Lauritz Larson, Brandywine Press, St. James, NY [1832].

Vaughan Alden T.

1989 "The origins debate: slavery and racism in seventeenth-century Virginia ", Virginia Magazine of History and Biography, 97, pp. 311-354.

White Owen

$1999 \quad$ Children of the French empire: miscegenation and colonial society in French West Africa, 1895-1960, Oxford University Press, Oxford UK.

WiLliamson Joel

1984 The crucible of race: black-white relations in the American South since emancipation, Oxford University Press, New York.

WOODWARD Comer Vann

1955 The strange career of Jim Crow, Oxford University Press, New York.

YúdICE George

1995 "Neither impugning nor disavowing whiteness does a viable politics make: the limits of identity politics ", in Christopher Newfield and Ronald Strickland (eds), After political correctness: the humanities and society in the 1990s, pp. 255-285, Westview Press, Boulder. 


\section{II/ AN UPDATE ON THE NEW HISTORY OF RACE IN AMERICA}

In 2002, I published a preliminary evaluation of " whiteness studies », a new genre of scholarly analysis that had emerged in a number of humanistic and social scientific disciplines in the 1990s. Focusing on historians' use of whiteness and paying particular attention to two influential historical studies, I found much to praise but also much to criticize in the new field. On the one hand, whiteness studies represented an innovative new way to emphasize the social construction of race in America and to attack the absurdity of white racism; on the other, they typically suffered from lack of precision in defining " whiteness », an exaggeration of whiteness's universal salience, and an inattention to both historical and historiographical context. I concluded by offering some tentative suggestions for where the field might go in the future and expressing the hope that « ten years from now, we will be able to conclude that it was in their second decade that whiteness studies really came of age » (Kolchin 2002, p. 173).

Since the completion of this article, studies on whiteness have continued to proliferate. Indeed, a keyword search reveals their accelerating rate of publication: whereas twenty-two books with « whiteness » in their titles appeared during the five years 1997-2001, twenty-eight such volumes were published during the period 2002-2006. As before, these volumes cover a broad range of disciplines from philosophy and art to education and literature, and works of history have more than held their own ${ }^{34}$.

In many ways, these new works resemble their whiteness studies forebears - and display the same weaknesses as well. Aiming to combat unconscious as well as conscious white racism, they typically employ personal anecdotes, raise present-minded concerns, and show a heavy dose of didacticism; as Jennifer Guglielmo observes in her introduction to a co-edited volume entitled Are Italians white?, " this collection teaches us about the power we have as individuals to take action against oppression in all its forms » (Guglielmo 2003, p. 5) ${ }^{35}$. As before, "whiteness " appears everywhere and nowhere, a concept reified and frequently poorly-defined: one author declares that « whiteness is not, yet we continue for many reasons to act as though it is ", while another sees in Princess Diana « not just an elevated feminine whiteness, but a reinscribed one, a representation of the cultural and affective power of the West » (López 2005, p. 1; Roberts 2005, p. 32). Too often, in their efforts to combat the evil of white racism, whiteness authors continue to offer strained and exaggerated arguments on the salience of whiteness, seeing it as underlying virtually all oppression and discrimination. Insisting that « Americanness has always undeniably meant whiteness », Linda Frost suggests that to the Confederate rebels during the Civil War, 
" to be non-American or Yankee meant occupying the space of the racialized, othered alien »; correctly noting Confederate portrayals of Yankees as «liars, beasts, and demons ", she provides no evidence at all linking this view to a perception of their being non-white (Frost 2005, pp. xii, xiv, 115) ${ }^{36}$.

Perhaps most striking is the extent to which recent " whiteness 》 scholarship appears to exist in a vacuum. My $J A H$ essay was hardly alone in raising serious conceptual questions about the whiteness studies of the 1990s. In the fall of 2001, historian Eric Arnesen published a far more slashing critique of the existing whiteness literature, attacking its imprecision, lack of empirical evidence, and strained reasoning and concluding that « the category of whiteness has to date proven to be an inadequate tool of historical analysis "; Arnesen's critique was accompanied by comments from six prominent historians, most of whom also expressed considerable discomfort with the current state of whiteness studies. Two years later, sociologist Margaret L. Andersen published a more restrained essay that subjected the sociological whiteness literature to criticisms that were in some ways remarkably similar to those I raised about the work of David R. Roediger and Matthew Frye Jacobson, especially deploring the reification of whiteness and the tendency of its authors to ignore material reality. And many book reviewers raised similar questions, although in necessarily abbreviated format ${ }^{37}$. For the most part, however, whiteness studies authors have continued to write as if their previous works had gone unchallenged, largely ignoring criticisms and even questions from without. Rarely has a scholarly discipline seeking to broaden horizons appeared quite so insular as whiteness studies.

Nevertheless, there are signs of hope. New works on whiteness are starting to appear that demonstrate a more sophisticated approach, both methodologically and interpretively, while existing whiteness scholars are partially retreating from exaggerated claims and grappling with new ways of exploring the subject. The recent evolution of " whiteness studies 》 - at least as practiced by historians can be highlighted by examining three new books: Thomas A. Guglielmo, White on arrival: Italians, race, color; and power in Chicago, 1890-1945, David R. Roediger, Working toward whiteness: how America's immigrants became white, and Matthew Frye Jacobson, Roots too: white ethnic revival in post-civil rights America. The first of these, a remarkable book by a young scholar, represents the most impressive work to date on whiteness, and suggests that in the right hands the field has a bright future. The second and third - by « founding fathers » of the discipline - show both the continued weight of past approaches and serious but only partially-successful efforts to overcome them (Guglielmo Thomas A. 2003; Roediger 2005; Jacobson 2006).

Focusing on Italian immigrants in Chicago from 1890 to 1945, White on arrival displays meticulous research and innovative analysis, in the process calling into question the standard narrative of an immigrant group « becoming » white. 
As the number of Italian immigrants in Chicago surged from 552 in 1870 to 59,215 in 1920, writes Guglielmo, they suffered from « extensive racial discrimination and prejudice », but primarily as Italians (or southern Italians), not as non-whites. Viewed by native-born Americans as inferior, « they were still generally accepted as white $»$; despite sporadic efforts in the early twentieth century to question their whiteness, " color challenges were never sustained or systematic ". Meanwhile, in terms of self-identification, regional and local loyalties at first remained paramount: while Italian-American newspapers such as L'Italia spoke of " la razza italiana » (not bianca), most Italian immigrants « clung instead to family and town loyalties » and " many newcomers seem to have treated "colored" and "white" groups similarly ». Rather than see themselves as white, nonwhite, or even Italian, they were more likely to identify as southern Italians (meridionali) or Sicilians. If Americans generally accepted them as white « on arrival ", to the immigrants themselves color seemed of little significance (Guglielmo Thomas A. 2003, pp. 7, 27, 28, 37) ${ }^{38}$.

Gradually, in the 1920s and 1930s, in the face of growing anti-immigrant sentiment (and restrictive legislation), the immigrants developed a growing sense of their Italianness - Italianitá - but whiteness itself still meant little to them; "When Italians looked down on African Americans, it was... because they thought Italians - not whites - were "the best"... », Guglielmo explains. « Italianitá and not whiteness was becoming most Italians' identity of choice ". Other Americans, meanwhile, while looking down on the Italians as "horrifyingly violent, lawless, treacherous, depraved, and immoral », continued to regard them as white; indeed, Italian-American gangsters such as $\mathrm{Al}$ Capone were seen as " white mobsters ", not as black or non-white. Significantly, even as many of the immigrant-Italians revealed their sense of Italianitá by expressing admiration for fascism in the 1930s, African-American spokesmen condemned the Italian invasion of Ethiopia as an example of white colonization of black Africa; in short, "African Americans insisted more on Italian whiteness than did Italians themselves » (Guglielmo 2003, pp. 57, 88, 77, 125).

Only in the 1940s did Italian-Americans increasingly identify as white, in part as they strove during World War II to stress their patriotic Americanness and play down their Italianitá, and in part as they sought to take advantage of homeowning opportunities and preserve property values. As this happened, there finally occurred both « a melding of race and color » and " an unmistakable declining significance of European race and a rising salience of Americanness ». For Italian-Americans, as for other Americans in the post-World War II era, « race " came to signify color, and distinctions that had once seemed racial came to be understood as « ethnic » (ibid., 2003, p. 162).

White on arrival represents an advance on several levels. Far more than previous whiteness studies, it is based on careful documentary research rather than clever supposition; rather than asserting the way Italians saw themselves, 
Guglielmo shows it. Carefully distinguishing between « race » and color, he also shows that although race could be color-based, it often was not: both native-born Americans and Italian immigrants themselves saw the existence of a distinctive Italian race (or nation), but in neither case was it based on their non-whiteness. While sharing with other whiteness authors an unfortunate tendency to blur precise attribution of behavior through use of the passive voice (« Were Italian immigrants and their children readily accepted as whites? ») (ibid., 2003, p. 4), he goes much further than most in disentangling self-perception from the views of others, thereby complicating the question of what it meant to "be " or " become » white. If most Americans saw Italian immigrants as white from the start, whiteness meant little in Italy, and most of the immigrants identified first by village or region and then by race or nation (as Italians), only much later coming to consider themselves whites (or Americans). In separating « race » from color; Guglielmo both acknowledges existing criticism of mainstream whiteness scholars and comes closer than others to raising an important question implicit but strangely ignored in the work of other whiteness scholars: Italians in America saw themselves as part of " la razza italiana ", which could variously be translated as the Italian race, nation, or people, but what exactly do these terms mean, and what is the relationship among race, nation, ethnicity, and people? ${ }^{39}$

Although David Roediger does not accept Guglielmo's distinction between race and color, in a number of ways he edges away from at least some of the positions put forth in The wages of whiteness, toward a more refined understanding of whiteness itself. Introducing a collection of essays that stresses the continued salience of "race " and ubiquity of white racism, for example, he warns against « so defensively insisting on the continuing relevance of race as to miss tremendous changes » that have occurred. Because " the props have been kicked from under much old-style racism » (including formal segregation, disfranchisement, and color-based immigration-restriction), he continues, the point is « not that struggles for racial justice must continue on the same terrain, but only that they must continue $»$. In short, racism - and presumably therefore whiteness as well - has changed (Roediger 2002, p. 15).

Even more important are hints of new thinking in Working toward whiteness. In many ways, this book is vintage Roediger. Displaying the same strong interest in language - although much less in class - as in The wages of whiteness, he also addresses the same basic problem: "becoming" white. This time, however, borrowing a leaf from Matthew Frye Jacobson's Whiteness of a different color, Roediger focuses on the whitening not of the native-born working-class or the Irish immigrants of antebellum years, but of the " new » European immigrants who came to the United States in the late nineteenth and early twentieth centuries. At first, he argues, in an account partially reminiscent of Guglielmo's, the immigrants did not consider themselves « white », but quickly - « so quickly... as 
to be virtually W[hite] $\mathrm{O}[\mathrm{n}] \mathrm{A}[$ rrival] » - they came to appreciate « the clear advantages of being white ». As the new immigrants « learned » whiteness (i.e., became racists), they gradually came to seem white to other Americans. Immigration restriction in the 1920 s made them appear less threatening, as did the increasing flow to northern cities of Mexican immigrants and southern blacks. Home ownership played an important role in this process of whitening, as upwardlymobile immigrants turned to restrictive covenants to keep African-Americans out of their neighborhoods and thereby protect property values. "New immigrant identification with whiteness ", writes Roediger, " would eventually turn on the defense of home and neighborhood ». By the end of World War II, " the ghet to had unequivocally become black, and eastern and southern Europeans far more securely a part of the master race » (Roediger 2005, pp. 119, 169, 244).

Lacking the excitement that novelty afforded The wages of whiteness, Working toward whiteness is in some ways a more sophisticated book than its predecessor. Roediger makes a greater effort than previously to distinguish between the self-perception of his subjects and their categorization by others (although the concept of "becoming " white continues to invite conflation of the two). Partially retreating from the idea that the immigrants were not (quite) white, Roediger now terms them «inbetween nationalities», a formulation that represents a modest improvement over "not white » but still suffers from the ambiguity of in between what? (Recognizing the problem, Roediger muses that " "in-among" may be a more apt, if cumbersome, term than inbetween ".) In fact, much of his evidence - although not his argument - indicates that rather than viewing new immigrants as in between white and black, many Americans saw them as inferior whites (a point that Jacobson established in Whiteness of a different color). "Yes, they're white but they're not our kind of white ", commented a Texas planter in objecting to the intermarriage of « Bohunks » (a term variously applied to Bohemians, Hungarians, and other central Europeans) and native white Americans. Roediger's solution to this problem is to suggest a differentiation between official and everyday categorization of new immigrants: whereas " in common speech » (and presumably, common thought) the new immigrants were less than white, academic experts and government officials accepted their whiteness. " The courts, Roediger concedes [...], consistently allowed new immigrants, whose racial status was ambiguous in the larger culture, to be naturalized as white citizens and almost as consistently turned down non-European applicants as nonwhite » (ibid., 2005, pp. 45, 50-51, $43,59,60)^{40}$.

Although this formulation represents an improvement over its predecessor, because it does not totally ignore evidence that Americans - at least officially accepted the immigrants' whiteness, Roediger continues to see discrimination against or hostility to particular categories of people (in this case, new immigrants) largely as a reflection of color prejudice, even when the evidence suppor- 
ting such a position is scanty. Occasionally he is able to cite racial epithets that may in fact have implied color judgments - it is plausible if not self-evident that the term " Guinea » (applied to Italians) suggested an African connection - but more often he assumes or asserts such an implication rather than showing it; he provides no evidence, for example, that "Greaser » (for Mexicans, and later Italians and Greeks) or " Hunky » (for Hungarians) indicated darkness or nonwhiteness. As before, Roediger continues to see virtually all discrimination through the lens of whiteness and non-whiteness, and thereby to reify race by insisting on its true meaning (ibid., 2005, esp. 37-45).

Indeed, Roediger seems curiously uncomfortable with what he terms the " messiness » or " lack of clarity » of racial categorizations, which (as Jacobson showed so well) were sometimes based on biological and sometimes on cultural assumptions and which have changed dramatically over time; some " experts ", Roediger notes, saw the world divided into three or four major races, whereas others listed dozens, including Jews, Irish, and English-speaking peoples. Although at times he seems to recognize this messiness as a function of the arbitrary and subjective character of race - a fundamental insight of whiteness studies - too often he steps away from this insight by insisting that race is (or should be) really about whiteness, as if race could have a real meaning aside from the social relations that engender it. In approaching the messiness of race, Roediger flirts with but ultimately misses an opportunity to probe a subject lurking in the background of all whiteness studies - the relationship among " race ", " nation ", and " ethnicity » as overlapping, constructed systems of categorization. If the original whiteness books by Roediger and Jacobson (The wages of whiteness and Whiteness of a different color) had never appeared, Working toward whiteness would no doubt seem a pathbreaking contribution, but it contains too little that is new and comes too close to embracing an " essentialist » understanding of race to fulfill its potential (ibid., 2005, esp. 3355 , pp. 35,51$)$.

Matthew Frye Jacobson's Roots too represents more of a new departure than Working toward whiteness. Focusing on white Americans' recent (re-)discovery - and celebration - of their ethnic roots, Jacobson turns from how the Irish, Jews, and Italians « became " white to how whites became (and are becoming) Irish, Jewish, and Italian. As this shift suggests, in contrast to his previous attention to how others saw and categorized immigrants, Jacobson's focus in this volume is on white ethnics' self-identification, a self-identification with strong political implications since it enables whites to deny their white racism by saying, "I'm not white; I'm Italian »... or Irish, or Jewish. But « however appealingly draped in a celebratory rhetoric of diversity and inclusion ", Jacobson asserts, the new American ethnic nationalism " is founded in large part on white primacy » (Jacobson 2006, pp. 1, 9). 
In a series of often compelling chapters, Jacobson describes a growing ethnic identification, beginning in the 1960s with « the group-based mobilization of the Civil Rights movement ", accelerating in the 1970 s with academic celebration of « diversity » and « multiculturalism », spreading to mass society in the 1970s and 1980s with the emergence of the "new ethnicity » on television and an ethnic revival (from Portnoy's complaint to The godfather) in American literature, and culminating in a pervasive celebration of "hyphenated " Americanism in the 1990s. The new interest in national heritage was embraced by - and served the purposes of - both Right and Left: if conservatives could rebut charges of anti-black racism by promoting a model whereby immigrants were able, through hard work and faith in America, to overcome prejudice and gain popular acceptance, radicals and feminists welcomed multiculturalism as a way to subvert a traditional order that they saw as run by and for rich white males. Suggesting that a sense of malaise and "national decline " underlies the new ethnic revival, Jacobson emphasizes the extent to which an apparently tolerant and accepting celebration of diversity in fact has reflected a continued - if muted - form of white racism: in the new celebration of hyphenated Americanism, he explains, " it must be the right kind of hyphen ". In short, the search for roots represents not the retreat from whiteness that it appears but rather a shift from « Plymouth Rock whiteness to Ellis Island whiteness » (Jacobson 2006, pp. 20, 314, 396, 7).

This determination to place the ethnic revival within the context of a commitment to whiteness represents not only the most salient theme but also the most problematical feature of an interesting book that grapples intelligently with an important subject. Of course, Jacobson is correct in asserting that white ethnic identification left plenty of room for hostility to blacks, and could enable conservatives to establish their own non-racist credentials by pointing to immigrants as role models for dissatisfied blacks. But his argument obscures the extent to which the new ethnicity represents a step away from whiteness. After all, the search for ethnic roots was by no means limited to white Americans: black Americans, too, embraced hyphenated Americanism (evident in the terms « Afro-American » and then "African-American »), sought to trace their African origins (an effort popularized in the wildly popular novel-turned-television-miniseries Roots), and displayed a new ethnic/racial pride (expressed in the idea that « black is beautiful » and the movement for "Black Power») (Haley 1976; Carmichael and Hamilton 1967). Equally important, in its broadest sense the new ethnic pride implied a retreat from whiteness (if also from common humanity): rather than identifying as whites, in implicit opposition to blacks or "non-whites ", Americans were choosing to see themselves as Italian-Americans, Irish-Americans, Jewish-Americans... and African-Americans, setting themselves off from everyone else, white or black.

Curiously, Jacobson ignores the critical question of how people determine - or choose - their ethnicity; in the process, like Roediger in Working toward 
whiteness, he comes close to reifying categories that are subjective and arbitrary. Large numbers of Americans - probably a majority - have multiple origins; in choosing to call themselves "Irish-American ", "Italian-American », or "African-American ", they are creating an ethnic identification for themselves rather than recognizing something real: ethnicity is invented, not discovered ${ }^{41}$. Many Americans see themselves as « multi-ethnic » and/or " multi-racial », and - in an implicit recognition of the subjective nature of any system of classification - the Census Bureau now allows Americans to list more than one racial and ethnic category to describe their identity, which millions of them choose to do ${ }^{42}$.

The essentializing and reification of "race» and "ethnicity" by both Roediger and Jacobson represent an unfortunate form of backsliding by scholars whose focus on " whiteness » originally aimed to subvert established categories and show their arbitrary character. Jacobson comes closer than Roediger to coming to grips with the complex, constructed nature of identity, and the relationship among race, ethnicity, and nation(ality) in shaping it, but ultimately he too shies away from the task of confronting how groups choose to define themselves - i.e., what makes a " people ». How whiteness studies can break out of their current limitations is a subject worthy of debate, but (as I will suggest below) I believe that one solution lies in placing both whiteness and the search for roots in a broader, multinational context. American whiteness, ethnicity, and identification are best understood not in isolation, but as part of a worldwide process.

Although both Roediger and Jacobson seem stuck between their old versions of whiteness and the demands of a new, more historically-based approach, other authors are likely to adopt at least some of Guglielmo's understanding. Indeed, this is already occurring. In a just-published article, for example, Carlos $\mathrm{K}$. Blanton specifically notes criticisms of the dominant whiteness scholarship and examines the career of Mexican-American civil rights leader George I. Sánchez in order to test whether in fact Mexican-Americans consciously chose to « become » white- i.e., whether they used white racism as a tactic to distinguish themselves from African-Americans and thereby raise their own status. Blanton concludes that in fact « Sánchez's civil rights career rebuts claims that Mexican Americans could not and did not cooperate with African Americans because the Mexican Americans had internalized whiteness » (Blanton 2006, p. 603).

But perhaps the most interesting revision of the traditional whiteness narrative, next to Guglielmo's, is to be found in Eric L. Goldstein's new book on the evolution of American Jewish identity. Although reluctant to repudiate the general concept of immigrants « becoming » white - he accepts at face value the validity of this process for Irish and Italians - Goldstein finds that it does not apply to Eastern European Jews, who from the beginning « were overwhelmingly seen as white ». Crucial here is the difference that Guglielmo stressed between 
race and color: although it was common in late-nineteenth and early-twentieth century America to consider Jews a distinctive race, most Americans did not see Jews as non-white. (Praising the "noble civilization » of Jews, the virulent anti-black racist Thomas Dixon criticized what he considered misguided efforts to equate the lynching of blacks with Russian anti-Jewish pogroms.) The concept of a " Jewish race » was also evident in Jews' self-perception: although Jewish identification evolved over time, before the mid-twentieth century - when « ethnic » and religious identification increasingly supplanted racial - Jews as well as gentiles typically accepted the notion of "Jewish distinctiveness » as « rooted not in cultural particularity but in biology, shared ancestry, and blood ». In short, the narrative of Jews' " becoming » white does not work, and Goldstein sees his story as « one that explores how Jews negotiated their place in a complex racial world" in which whiteness was not the only salient characteristic. Goldstein does not always fully appreciate the significance of his own evidence: he undervalues the importance of the distinction between race and color and - in a reaction reminiscent of Roediger's to the "messiness » of race - he seems bothered by the indeterminate and changing meaning of « Jew 》 (to both Jews and gentiles) rather than seeing such variation as inherent in the subjective nature of «race». Still, The price of whiteness represents a major improvement over Karen Brodkin's ahistorical approach to Jewish identity, and indicates - together with Guglielmo's work - a new maturity in whiteness studies (Goldstein 2006, pp. 17, 46, 11, 5; Brodkin 1998).

Indeed, there is reason to hope that the basis is being laid for whiteness studies to move toward their potential of advancing our understanding of how Americans - and other people - see both themselves and others, what circumstances shape these perceptions, and how "race" and "whiteness " relate to other ingredients in this process. Although this is not the place for a full analysis of " what is to be done ", the following comments, queries, and speculations are designed to suggest some possible avenues for further exploration as the field matures. They should be regarded not as fully-developed arguments so much as tentative thoughts for discussion.

I would begin by reiterating the importance of placing American whiteness - and « race» in general - in broad international context. Although whiteness authors have usually written about developments in the United States as if they occurred in a vacuum, it should be evident that many of the central questions of concern to these authors - « racial » prejudice, the self-identification of immigrants, the relationship between color and race, the tension between integrating into mainstream society and maintaining one's own identity (however defined) are problems besetting other countries as well as the United States. What is more, they do not represent an entirely new phenomenon. Although whiteness studies have focused on the nineteenth and twentieth centuries, and it has become part of the accepted orthodoxy that racism is a recent curse that has reached its full 
fruition only in modern egalitarian societies, Benjamin Isaac's detailed exploration of "proto-racism » in the Ancient world raises important questions about the roots of racial thought, and whether prejudice against "non-whites » constitutes simply one stage and one form of a pervasive chauvinism that has been endemic to human history (Isaac 2004) ${ }^{43}$.

An essential question that whiteness authors have largely ignored is why we are now witnessing growing racial, ethnic, and national identification in both the United States and much of the world, and what the relationship is between this new trend and apparently similar developments in the past. Among the wide variety of overlapping ways that people have categorized both others and themselves - religion, class, occupation, geography, intellect, gender, race, color some have seemed particularly salient in certain eras, only to fade into obscurity, while others have proved surprisingly enduring after appearing for a time to be of diminishing concern. Because Jacobson pays little attention to the relationship between ethnic and other forms of identification, he cannot establish whether ethnic pride has, in fact, eclipsed those other forms as fully as he believes. What, one might ask, of the almost-ethnic consciousness of white southerners, forged in regional hostility to both "Yankees » and a strong central government, a consciousness recently explored by journalist Tony Horwitz in his fascinating book Confederates in the attic (Horwitz 1998) ${ }^{44}$. The immigrant-ethnic identification that Jacobson emphasizes, while important, can be seen as part of a larger process of growing particularism, whether based on national origin, region, or religion ${ }^{45}$. Millions of Americans, for example, no matter what their " roots ", now identify more strongly as evangelical Christians than anything else, while for others a commitment to Islam is primary, cutting across any ethnic or racial identity. Here, once again, placing the American developments in broader international context would be useful.

There are no doubt many reasons for the recent rise in ethnic tensions and national consciousness, including the unprecedented scope of international migration that has brought together diverse nationalities in numbers unprecedented as well. I believe, however; that just as a profound sense of political disillusionment helps explain the emergence of whiteness studies as a discipline (Kolchin 2002, p. 167), so too a declining belief in the possibility of progressive social change (resulting in part from the collapse of a world socialist movement and the virtually-unquestioned hegemony of market capitalism) underlies a major reordering of human aspirations, one element of which is an accentuation of ethnic/national identification. For more than two centuries - since at least the last quarter of the eighteenth century - « enlightened » thought has accepted the notion of human progress, and people have struggled to remake the world (or their worlds) on behalf of a social vision informed by belief first in republicanism, and then in varying versions of democracy, socialism, and feminism. Now, in an era when for the first time in modern history there appears to be little potential for 
such progressive change, people who at one time would have put their hope in the struggle for social justice are turning to a renewed emphasis on ethnicity, nationalism, local or regional attachments, and religion (others, yielding to the logic of the market, see their salvation in acquisition of material goods). I would propose that the American search for roots can best be understood in this context as well.

As whiteness scholars strive to make sense of the evolving ways in which Americans (and non-Americans) have categorized themselves and others, more sustained attention to the relationship among race, ethnicity, and nation - all of which are concepts that have been described as " constructed ", " invented ", and "imagined »- would seem to be in order ${ }^{46}$. Roediger's emphasis on the " messiness » of race is surely pertinent here: Americans' understanding of race has not only evolved over time, but has often overlapped with or even approximated what in other times was seen not as race but as ethnicity or nationality. Because even as they argue for its constructed nature Roediger and to a lesser extent Jacobson essentialize race by insisting that its true essence is related to color and that whiteness lurks behind all other prejudice, the works of Guglielmo, Goldstein, and Isaac are important as correctives; they reveal what should have been self-evident all along, that there have been many ways to oppress or discriminate against humans, and that - despite the virulence of white racial prejudice - whiteness has not always been at the center of such oppression and discrimination ${ }^{47}$.

Helpful in unraveling some of the complexity of racial terminology in the United States is a recent essay by Donna Gabaccia, who points out the unusual way that Americans have conceptualized "nation ». Whereas Americans have generally developed a " civic » concept of nationhood, using the term " nation " to mean " nation-state » or " country » composed of voluntary citizens (" the United States is a great nation »), in Italy, Germany, and much of central and eastern Europe " nationalists helped to make race and nation loosely interchangeable terms "; both signified a people or " descent group " rooted in biology. Largely unaware that « for speakers of other languages, nations themselves are ethnic groups (and sometimes are still called races)... or that nationalism itself can be suspect as a form of racism ", Americans frequently find it puzzling that " [o]utsiders commenting on the hyphenated identities so common in the Englishspeaking world are often explicit in labeling them racial expressions » (Gabaccia 2003 , pp. $46,59,58)^{48}$.

In fact, some of these overlapping meanings of race and nation are also evident in the United States, despite the supposedly clear distinctions among race, ethnicity, and nation. When Italian-Americans spoke of "la razza italiana » they were expressing this widespread, " un-American » view of peoplehood: Italians - wherever they lived - were part of the Italian race or nation. Similar " racial » identification has been evident among other immigrants groups, from Latinos to Chinese (as has "national» identification among African-Americans, who 
supposedly constituted a "race »). But the "messiness » of both American categorization and self-identification is perhaps most clearly evident among Jews, who as Goldstein shows once appeared (to themselves and others) to constitute a race but now are almost never so described. If most Americans think they see Jewishness defined by either religion or (cultural) ethnicity - it would be unacceptable, " racist ", to describe Jews as a race - they belie this perception by continuing to categorize as Jews those who lack religious or cultural manifestations of Jewishness; the concept of a non-religious Jew is incompatible with a religious definition of being Jewish, just as the concept of a totally « assimilated » Jew (who does not « act » Jewish) is incompatible with an ethnic (i.e., cultural) definition. Most Americans (and most American Jews) continue unconsciously to apply a racial understanding to Jewishness, seeing anyone with Jewish parents (or; for followers of official Jewish doctrine, mother) as Jewish (Goldstein 2006) ${ }^{49}$.

The thin line separating American understandings of race and ethnicity received graphic illustration recently in the New York Times Magazine. Writing in the weekly advice column, "The Ethicist », Randy Cohen responded to a reader's question concerning whether the reader's brother, who had just learned that he was not - as he had previously believed - " part Indian ", was morally obligated to repay an education grant earmarked specifically for Native Americans. Taking the rejection of racial categorization to its logical extreme, Cohen replied that being Indian was (like being white for Roediger) a matter of choice, not genetics: « When invoking ethnicity, universities are - or should be - concerned not with genetics but with culture, with life as it's actually lived. If a DNA test had shown your brother to be 20 percent Cherokee, so what? He did not live as a Cherokee. His Cherokee forebears did not affect his behavior. And so he ought not check the Cherokee box on any application ". My guess is, however, that most Americans would not agree with this judgment. They may have advanced to the stage where they would allow people to choose their ethnicity from among valid options (i.e., someone with German, Italian, and African ancestry can legitimately choose whether to "be " German-American, Italian-American, AfricanAmerican, mixed race, or simply American) but not from an open-ended list; someone with German, Italian, or African ancestry cannot claim to be « FrenchAmerican » just because he or she has a keen appreciation of French culture (Cohen 2006) ${ }^{50}$.

The question of the relationship between a racial/ethnic/national understanding of identity and one provided by religion is both important and largely ignored by Roediger and Jacobson. Here, countervailing trends are in evidence. On the one hand, religion has frequently fostered national or ethnic identification. In the nineteenth-century, most Americans saw themselves as a Protestant people - and indeed, saw the United States as a Protestant nation. Throughout the world, religion has sometimes served as a unifying national force, providing 
political cohesion in struggles for national independence (as in Poland or Ireland) but then (at least sometimes) becoming less salient once that independence is achieved. Where countries have been based on super-national federations, confederations, or empires - the Soviet Union, Yugoslavia, Iraq - religion has often served as a dividing force, fomenting secessionist movements and nationalist divisions. In such cases, religion comes close to constituting a basis for ethnicity. Recently, the New York Times has started referring to those whom it used to call "Sunni Muslims» as "Sunni Arabs », suggesting that in fact they form a separate ethnic group (nation? race?) rather than just a religion, and referring as well to « secular Sunni Arabs » (the counterpart of non-observant Jews) ${ }^{51}$. But on the other hand, religion can clearly cut across racial, ethnic, or national identification, as is evident in those Americans for whom evangelical Christianity provides a stronger basis of identification than national origin, color, or occupation, or people elsewhere for whom being a Muslim (or the right kind of Muslim) is more important than anything else. Should one regard this kind of religious identification as itself essentially ethnic, or even racial, in nature? It is common now for evangelical Christians to speak of anti-evangelical « bigotry » as the last socially-acceptable (" politically-correct ») form of prejudice in the United States, just as Muslims sometimes speak of anti-Muslim « racism »- a concept that implies the existence of a Muslim "race». Once again, we are back to the subjective character of race itself.

Finally, even as we move away from an exclusive emphasis on whiteness and non-whiteness in the making of "race», it is important to acknowledge and address the distinctiveness of both the African-American experience and of anti-black racism. Unlike most other Americans, the great majority of AfricanAmericans are descended from people brought to the New World against their will and held as slaves, and there has been a particular intensity to the racism directed at African-Americans, an intensity that goes far toward explaining why some scholars see whiteness lurking behind almost all American racism. There is, of course, a lengthy historiography to anti-black racism and the chicken-or-egg question of its relationship to slavery, and it is impossible to revisit that issue here, except to note that it remains contested ${ }^{52}$. The slave experience of AfricanAmericans was distinctive, but at particular points in time other groups - most obviously Native Americans - suffered treatment that was equally barbarous, and elsewhere in the world the hostility meted out to Jews defies an easy situational explanation of racism as rationalization of self-interest. As whiteness authors continue their effort to explain the evolving nature of race and racism in America, they must continue to confront in anti-black prejudice a particular manifestation of racism that is simultaneously unique and part of a broader phenomenon, and to work toward clarifying the relationship between the two.

The field of whiteness studies appears to be at a turning point, on the verge of producing major new contributions to our understanding of how Americans 
have related to one another, but only if its practitioners are prepared to move beyond some of its original limitations. These include, among others, a lack of empirical research, an exaggeration of the universal salience of color in human categorization and self-identification, a concomitant tendency to reify whiteness (and race itself), and an insularity manifested both in a lack of attention to criticism and in a lack of attention to broad international context. Still, signs of growing sophistication among whiteness scholars provide grounds for cautious optimism. There is no guarantee that whiteness studies will fulfill the hope that I expressed at the end of my $J A H$ article, but it remains a real possibility. *

* Manuscrit reçu en septembre 2007, accepté pour publication en janvier 2008.

\section{NOTES}

34. Representative titles outside of history include Sullivan (2006 - philosophy), Berger (2005 - art), Wray (2006 - sociology), Taylor (2005), Frost (2005) and Traber (2007-literature). See also the " revised and expanded » edition of the 1998 book by American studies scholar George Lipsitz (2006). Before 1997, there were very few " whiteness " titles: 1992-96-6; 1987-1991-2; 1982-86-1; and 1977$81-0$.

35. In this collection's first essay, literary scholar Louise DeSalvo (2003, p. 28) focuses on her grandmother's naturalization, beginning with a detailed account of her own interaction with her father, who did not properly appreciate the value of family documents that shed light on how in America her grandmother became « someone not truly white ». See, also, the introductory chapter to a new set of essays by David R. Roediger (2002, p. 16), in which he notes his « emphasis... on identifying not a "usable past" but a "usable present" ".

36. Similarly, Matt Wray's categorization of antebellum southern poor whites as " not quite white » depends on his redefinition of " white as a social category, not a racial category » (Wray 2006, p. 139). For an essay that subsumes anti-Gypsy prejudice under the whiteness banner, see Imre (2005).

37. See "Scholarly controversy: whiteness and the historians' imagination », International labor and working-class history, 60, 2001, pp. 1-92, including Eric Arnesen, "Whiteness and the historians' imagination ", pp. 3-32, with comments by James R. Barrett (pp. 33-42), David Brody (pp. 43-47), Barbara J. Fields (pp. 48-56), Eric Foner (pp. 57-60), Victoria C. Hattam (pp. 61-68), and Adolph Reed, Jr. (pp. 69-80), and a final response by Eric Arnesen (pp. 81-92). See Andersen (2003) and Gerber (1999). See, also, Eric Arnesen's essay-review (2002) of David R. Roediger's Colored white, Wickberg (2005), and book reviews cited in Kolchin, "Whiteness Studies I 》.

38. Most Italian immigrants to the United States came from the South, where regional and local identities were strong, a sense of Italianitá was weak, and only the educated or landowning elite was likely to speak Italian. On the persistence in Italy of negative stereotypes about the "backward " South, see Gribaudi (1997) and Dickie (1997). For recent comparative investigations, see Dal Lago and Halpern (2002) and Doyle (2002).

39. Politically-active Latinos in the United States have referred to themselves, similarly, as members of " la raza ». See Garcia (1999).

40. "At the level of legal and academic expertise... ", Roediger (p. 50) observes " there was broad agreement that eastern and southern Europeans were white ».

41. For two somewhat differing versions of the invention (or construction) of ethnicity, see Sollors (1989) and Conzen et al. (1992).

42. The changing policies of the Census Bureau can be traced in a series of articles in the New York Times. Noting that «the Government has found a new way to classify its people virtually every 
decade ", reporter Felicity Barringer (1993) observed that « in 1990, about 28 percent of those answering an open-ended "ancestry" question listed two or more ethnic groups, like "Irish and Ukrainian". But some children of white-black or white-Asian parents identify simply as "mixed", and they want the census to let them do this officially ». The 2000 census expanded the number of " races " from four to five (white, black, American Indian/Alaskan Native, Asian, and Native Hawaiian/Pacific Islander), categorized " Hispanic » as an ethnic group rather than a race, and allowed respondents to choose any combination they wanted, « resulting in 63 racial classifications for non-Hispanics and 63 for Hispanics "; as the director of the Office of Management and Budget put it, " we're allowing people to express that multiracial heritage in whatever way they view themselves ". At the same time, the Census Bureau decided that those who chose to call themselves both "white " and members of a minority group should be counted in the latter category (Holmes 1997; 2000). For earlier census policy, see Anderson (1988).

43. On the link between egalitarian modernity and racism, see Fredrickson (2002, passim, esp. 11-12).

44. There is, if course, a long history to such southern identification: see Kolchin (2003, pp. 7-38).

45. In her comment on the earlier version of this article, delivered at the conference on " "Race", "ethnie" et "communauté" aux Amériques » (EHESS, Paris, 15 December 2006), Stefania Capone noted the effort to form a "Yoruba-American identity " described in her book (2005); " Blackness », she observed, « is thus but one step towards the acquisition of an "ethnic" identification via a religious identification ".

46. For major works emphasizing the constructed nature of " nations ", see Benedict Anderson (1991); Hobsbawm and Ranger (1983); Hobsbawm (1990); and Geary (2002).

47. The term " racism " is of relatively recent origin, emerging in the first half of the twentieth century to describe belief in the superiority of « Nordic » races; it was at first applied far more often to Nazi anti-semitic ideology than to anti-black thought or action. Only in the 1960 s, George Fredrickson explains, did racism " come into general use to describe attitudes toward African Americans " (Fredrickson 2002, p. 167).

48. For a similar observation on the frequent conflation in English of nation and state, see Wecks (1996, pp. 4-8). On the tension between civic versus racial versions of American nationalism, see Gerstle (2001). For studies that place American nationalism - and understandings of " nation " - in broad international context, see Parish (1995); and Doyle and Pamplona (2006).

49. " Jews often defined themselves publicly as a religious group ", writes Goldstein (ignoring the sizable number of non-observant American Jews), « while privately pursuing Jewishness as a tribal phenomenon " (Goldstein 2006, p. 206). For a recent historical work exploring - and stressing African-Americans' sense of nationality or peoplehood, see Hahn (2003).

50. On the continuing controversy over who qualifies to be considered a Cherokee, the role of " blood " in this determination, and a recent effort to exclude black and " mixed race " descendants of those long accepted as members of the Cherokee Nation, see Nieves (2007).

51. A «ProQuest» database search reveals that the first New York Times reference to "Sunni Arab " occurred on 7 January 1980 (p. A3), but the term rarely appeared until recently: during the 21 years 1980-2001, the Times used "Sunni Arab » 21 times, for an average of once a year, but in the two years 2002 and 2003 the paper used the term 37 times, averaging 18.5 times per year. The shift to more frequent usage began on 19 May 2002. Although the ProQuest database does not cover years later than 2003, an impressionistic survey suggests that during the past year - following a period during which both terms were used - "Sunni Arab » has completely or almost completely replaced «Sunni Muslim » in the Times. Recently the paper has taken this practice one step further, referring to " each ethno-religious group - Kurd, Sunni Arab, and Shiite Arab »; "Shiite » and "Sunni » have gone from being religious to being "ethno-religious » designations, on a par with "Kurd " (which bears no religious connotation). See Cooper (2007).

52. For early enunciation of the argument that slavery led to racism in the American colonies, see Handlin Oscar and Mary F. (1950). Others countered that racial prejudice against blacks preceded 
- and made possible - the enslavement of Africans; see Degler (1959); and Jordan (1968). Much of the debate is covered in Vaughan (1989). In the most recent contribution to this question, Davis (2006, esp. 48-102) puts forth a largely cultural explanation of racism, and places the American South in broad international perspective.

\section{REFERENCES CITED}

\section{ANDERSEN Margaret L.}

2003 "Whitewashing race: a critical perspective on whiteness ", in Ashley W. Doane and Eduardo Bonilla-Silva (eds), White out: the continuing significance of racism, Routledge, New York, pp. 21-34.

\section{ANDERSON Benedict}

1991 Imagined communities: reflections on the origin and spread of nationalism, Verso, $2^{\text {nd }}$ ed., London.

\section{ANDERSON Margo J.}

1988 The American census: a social history, Yale University Press, New Haven.

\section{ARNESEN Eric}

2002 Review of David R. Roediger's Colored white, "A paler shade of white ", The New Republic, 24 June, pp. 33-38.

\section{BARRINGER Felicity}

1993 "Ethnic pride confounds the census », New York Times, 9 May, p. E3.

Berger Martin A.

2005 Sight unseen: whiteness and American visual culture, University of California Press, Berkeley.

BLANTON Carlos K.

2006 " George I. Sánchez, ideology, and whiteness in the making of the Mexican American civil rights movement, 1930-1960 », Journal of Southern History, 72 (August), pp. 569-604.

BRoDKIN Karen

1998 How Jews became white folks and what that says about race in America, Rutgers University Press, New Brunswick.

\section{CAPONE Stefania}

2005 Les Yoruba du Nouveau Monde: religion, ethnicité et nationalisme noir aux États-Unis, éditions Karthala, Paris.

Carmichael Stokely and Charles V. Hamilton 1967 Black power: the politics of liberation in America, Random House, New York.

\section{COHEN Randy}

2006 "The Ethicist », New York Times Magazine, 6 August. 


\section{CONZEN Kathleen Neil et al.}

1992 "The invention of ethnicity: a perspective from the U.S.A. ", Journal of American Ethnic History, 12 (fall), pp. 3-41.

\section{COOPER Helene}

2007 «Iraq Math, from one, make three », New York Times, 29 July, section 4, p. 1.

Dal LAgo Enrico and Rick HaLPERN (eds)

2002 The American South and the Italian Mezzogiorno: essays in comparative history, Palgrave, Houndsmill, UK.

DAvis David Brion

2006 Inhuman bondage: the rise and fall of slavery in the New World, Oxford University Press, New York.

DEgLer Carl N.

1959 "Slavery and the genesis of American race prejudice ", Comparative Studies in Society and History, 2 (October), pp. 49-66.

DeSalvo Louise

2003 "Color: white/complexion: dark », in Jennifer Guglielmo and Salvatore Salerno (eds), Are Italians white? How race is made in America, Routledge, New York and London, pp. 17-28.

DICKIE John

1997 "Stereotypes of the Italian South, 1860-1900 ", in Robert Lumley and Jonathan Morris (eds), The new history of the Italian South: the Mezzogiorno revisited, University of Exeter Press, Exeter, UK, pp. 114-147.

DOYLe Don H.

2002 Nations divided: America, Italy, and the Southern question, University of Georgia Press, Athens, GA.

Doyle Don H. and Marco Antonio Pamplona (eds)

2006 Nationalism in the New World, University of Georgia Press, Athens, GA.

FREDRICKSON George M.

2002 Racism: a short history, Princeton University Press, Princeton.

Frost Linda

2005 Never one nation: freaks, savages, and whiteness in U. S. popular culture, 1850-1877, University of Minnesota Press, Minneapolis.

Gabaccia Donna R.

2003 «Race, nation, hyphen: Italian-Americans and American multiculturalism in comparative perspective ", in Jennifer Guglielmo and Salvatore Salerno (eds), Are Italians white? How race is made in America, Routledge, New York and London, pp. 44-59.

GARCIA Ignacio M.

1999 United we win! The rise and fall of La Raza Unida Party, MASRC, University of Arizona, Tucson, AZ. 
Geary Patrick J.

2002 The myth of nations: the medieval origins of Europe, Princeton University Press, Princeton.

\section{Gerber David A.}

1999 «Caucasians are made and not born: how European immigrants became white people ", Reviews in American History, 27, pp. 437-443.

\section{GerstLe Gary}

2001 American crucible: race and nation in the twentieth century, Princeton University Press, Princeton.

\section{Goldstein Eric L.}

2006 The price of whiteness: Jews, race, and American identity, Princeton University Press, Princeton.

\section{Gribaudi Gabriella}

1997 "Images of the South: the Mezzogiorno as seen by insiders and outsiders », in Robert Lumley and Jonathan Morris (eds), The new history of the Italian South: the Mezzogiorno revisited, University of Exeter Press, Exeter, UK, pp. 83-113.

\section{Guglielmo Jennifer}

2003 «Introduction: white lies, dark truths », in Jennifer Guglielmo and Salvatore Salerno (eds), Are Italians white? How race is made in America, Routledge, New York and London, pp. 1-14.

\section{Guglielmo Jennifer and Salvatore SALERNo (eds)}

2003 Are Italians white? How race is made in America, Routledge, New York and London.

\section{Guglielmo Thomas A.}

2003 White on arrival: Italians, race, color; and power in Chicago, 1890-1945, Oxford University Press, New York.

\section{HaHN Steven}

2003 A nation under our feet: black political struggles in the rural South from slavery to the great migration, Harvard University Press, Cambridge, MA.

HaLey Alex

1976 Roots, Doubleday, Garden City, NY.

HANDLIN Oscar and Mary F. HANDLin

1950 "Origins of the Southern labor system ", William and Mary Quarterly, 7, pp. 199-222.

HobsBawm Eric J.

$1990 \quad$ Nations and nationalism since 1780: programme, myth, reality, Cambridge University Press, Cambridge, UK.

Hobsbawm Eric J. and Terence Ranger (eds)

1983 The invention of tradition, Cambridge University Press, Cambridge, UK. 
Holmes Steven A.

1997 "People can claim one or more races on federal forms », New York Times, 30 October, p. A1.

2000 «New policy on census says those listed as white and minority will be counted as minority ", New York Times, 11 March, p. A9.

HoRwitz Tony

1998 Confederates in the attic: dispatches from the unfinished Civil War, Pantheon, New York.

IMRE Anikó

2005 "Whiteness in post-socialist Eastern Europe: the time of the Gypsies, the end of race ", in Alfred J. López (ed.), Postcolonial whiteness: a critical reader on race and empire, State University of New York Press, Albany, NY, pp. 79-102.

IsAAC Benjamin

2004 The invention of racism in classical antiquity, Princeton University Press, Princeton.

JACOBSon Matthew Frye

1998 Whiteness of a different color: European immigrants and the alchemy of race, Harvard, Cambridge, Mass.

2006 Roots too: white ethmic revival in post-civil rights America, Harvard University Press, Cambridge, MA.

JORDAN Winthrop D.

1968 White over black: American attitudes toward the Negro, 1550-1812, University of North Carolina Press, Chapel Hill.

\section{Kolchin Peter}

2002 "Whiteness studies: the new history of race in America », Journal of American History, 89, 154-173.

2003 "The South and the Un-South ", in his A sphinx on the American land: the nineteenth-century South in comparative perspective, Louisiana State University Press, Baton Rouge, LA.

Lipsitz George

2006 The possessive investment in whiteness: how white people profit from identity politics, Temple University Press, Philadelphia [1998].

LÓPEZ Alfred J.

2005 "Introduction: whiteness after empire », in Alfred J. López (ed.), Postcolonial whiteness: a critical reader on race and empire, State University of New York Press, Albany, NY, pp. 1-30.

Nieves Evelyn

2007 "Putting to a vote the question "who is Cherokee?" ", New York Times, 3 March, p. A3. 
PARISH Peter J.

1995 "An exception to most of the rules: what made American nationalism different in the mid-nineteenth century? », Prologue: Quarterly of the National Archives, 27 (Fall), pp. 219-229.

ROBERTS Diane

2005 " The body of the princess », in Alfred J. López (ed.), Postcolonial whiteness: a critical reader on race and empire, State University of New York Press, Albany, NY, pp. 31-52.

ROEDIGER David R.

2002 Colored white: transcending the racial past, University of California Press, Berkeley.

$2005 \quad$ Working toward whiteness: how America's immigrants became white - the strange journey from Ellis Island to the suburbs, Basic Books, New York.

SolLoRs Werner

1989 "Introduction: the invention of ethnicity », in Werner Sollors (ed.), The invention of ethnicity, Oxford University Press, New York, pp. ix-xx.

SULLIVAN Shannon

2006 Revealing whiteness: the unconscious habits of racial privilege, Indiana University Press, Bloomington, IN.

TAYLOR Gary

2005 Buying whiteness: race, culture, and identity from Columbus to hip hop, Palgrave Macmillan, New York.

Traber Daniel S.

2007 Whiteness, otherness, and the individualism paradox from Huck to punk, Palgrave Macmillan, New York.

VAUGHan Alden T.

1989 "The origins debate: slavery and racism in seventeenth-century Virginia », Virginia Magazine of History and Biography, 97 (July), pp. 311-354.

WeEks Theodore R.

1996 Nation and state in late imperial Russia: nationalism and russification on the Western frontier, 1863-1914, Northern Illinois University Press, DeKalb, IL.

WickBerg Daniel

2005 "Heterosexual white male: some recent inversions in American cultural history ", Journal of American History, 92 (June), pp. 136-157.

WraY Matt

$2006 \quad$ Not quite white: white trash and the boundaries of whiteness, Duke University Press, Durham, NC. 